\title{
Structure and high temperature mechanical properties of novel non- equiatomic Fe-(Co, Mn)-Cr-Ni-Al-(Ti) high entropy alloys
}

\author{
N.D. Stepanov ${ }^{a, *}$, D.G. Shaysultanov ${ }^{a}$, M.A. Tikhonovsky ${ }^{b}$, S.V. Zherebtsov ${ }^{a}$ \\ a Laboratory of Bulk Nanostructured Materials, Belgorod National Research University, Belgorod, 308015, Russia \\ ${ }^{\mathrm{b}}$ National Science Center "Kharkov Institute of Physics and Technology" NAS of Ukraine, Kharkov, 61108, Ukraine
}

\section{A R T I C L E I N F O}

\section{Keywords:}

High entropy alloys

Alloy design

Mechanical properties

Phase stability

Prediction

\begin{abstract}
A B S T R A C T
Four non-equiatomic Fe-(Co, Mn)-Cr-Ni-Al-(Ti) high entropy alloys, namely $\mathrm{Fe}_{36} \mathrm{Mn}_{21} \mathrm{Cr}_{18} \mathrm{Ni}_{15} \mathrm{Al}_{10}$, $\mathrm{Fe}_{36} \mathrm{Co}_{21} \mathrm{Cr}_{18} \mathrm{Ni}_{15} \mathrm{Al}_{10}, \mathrm{Fe}_{35} \mathrm{Mn}_{20} \mathrm{Cr}_{17} \mathrm{Ni}_{12} \mathrm{Al}_{12} \mathrm{Ti}_{4}$, and $\mathrm{Fe}_{35} \mathrm{Co}_{20} \mathrm{Cr}_{17} \mathrm{Ni}_{12} \mathrm{Al}_{12} \mathrm{Ti}_{4}$ alloys, were produced by arc melting. Structures and compression mechanical properties of the as-cast alloys were examined. The $\mathrm{Fe}_{36} \mathrm{Co}_{21} \mathrm{Cr}_{18} \mathrm{Ni}_{15} \mathrm{Al}_{10}$ alloy had mostly a face-centered cubic (fcc) structure, while $\mathrm{Fe}_{36} \mathrm{Mn}_{21} \mathrm{Cr}_{18} \mathrm{Ni}_{15} \mathrm{Al}_{10}$ mainly consisted of a body-centered cubic (bcc) matrix with embedded B2 precipitates. An addition of Ti resulted in the formation of $\mathrm{L} 2_{1}$ precipitates of a cuboidal shape mostly in the $\mathrm{Fe}_{35} \mathrm{Mn}_{20} \mathrm{Cr}_{17} \mathrm{Ni}_{12} \mathrm{Al}_{12} \mathrm{Ti}_{4}$ and of a plate-like shape in the $\mathrm{Fe}_{35} \mathrm{Co}_{20} \mathrm{Cr}_{17} \mathrm{Ni}_{12} \mathrm{Al}_{12} \mathrm{Ti}_{4}$ alloys. In addition, a significant amount of the fcc phase (0.17) was found in the latter alloy. Good correlation between the average valence electron concentration (VEC) value and the amount of the fcc phase in the experimental alloys was found. The comparison of the experimental data with results obtained using a Thermo-Calc software and a TCHEA2 database demonstrated a lack of credibility in the L2 ${ }_{1}$ phase formation predicting. In terms of the mechanical properties, the $\mathrm{Fe}_{36} \mathrm{Co}_{21} \mathrm{Cr}_{18} \mathrm{Ni}_{15} \mathrm{Al}_{10}$ alloy was rather soft, while the $\mathrm{Fe}_{36} \mathrm{Mn}_{21} \mathrm{Cr}_{18} \mathrm{Ni}_{15} \mathrm{Al}_{10}$ and $\mathrm{Fe}_{35} \mathrm{Mn}_{20} \mathrm{Cr}_{17} \mathrm{Ni}_{12} \mathrm{Al}_{12} \mathrm{Ti}_{4}$ alloys had high strength at temperatures of $\leq 400{ }^{\circ} \mathrm{C}$. The $\mathrm{Fe}_{35} \mathrm{Co}_{20} \mathrm{Cr}_{17} \mathrm{Ni}_{12} \mathrm{Al}_{12} \mathrm{Ti}_{4}$ alloy had the highest strength among the examined alloys and maintained the strength at temperatures up to $600^{\circ} \mathrm{C}$. The correlation between the mechanical properties and structure of the non-equiatomic Fe-(Co, Mn)-Cr-Ni-Al-(Ti) high entropy alloys and a potential for further improvements of the properties are discussed.
\end{abstract}

\section{Introduction}

The so-called high entropy alloys (HEAs) have become a major research topic in materials science in the recent years [1-4]. The HEAs are different from the conventional alloys in their complex, multiprincipal element chemical composition. According to the original definition they are composed of at least 5 principal elements taken in nearly equiatomic proportions (5-35 at.\%) [5]. It is thus believed that HEAs can possess unique structures and properties not attainable in conventional alloys and can therefore be attractive materials for advanced applications [2,6].

One of the particularly promising application areas for HEAs is their usage as high-temperature materials [2,6-8]. Indeed, many HEAs have demonstrated remarkable mechanical properties at elevated temperatures [6,9-18]. Although in the initial studies the main attention has been focused on solid solution single phase HEAs, it is believed that the solid solution matrix needs to be strengthened by second phase(s) precipitates to maintain high strength at elevated temperatures $[19,20]$.
Such an approach is widely used with respect to high-temperature alloys (Ni-based superalloys, for example) design. In the Ni-based superalloys a face-centered cubic (fcc) matrix is strengthened by fine precipitates of a $\mathrm{Ni}_{3}(\mathrm{Al}, \mathrm{Ti})$ phase with an $\mathrm{L}_{2}$ structure [21]. Similar kind of microstructure (the fcc matrix with the $\mathrm{L}_{2}$ precipitates) can be produced in some HEAs [22-28]; in Refs. [25,27] such alloys have been referred to as high entropy superalloys (HESAs). It was reported recently that HESAs can offer some improved properties in comparison with the conventional Ni-based superalloys [8].

Meanwhile different types of the superalloy-like microstructure can be produced in HEAs based on 3d transition metals. In Refs. [29-34] a structure of HEAs was found to be composed of a body-centered cubic (bcc) matrix with embedded B2 precipitates. The bcc/B2 alloys can offer high strength at room and elevated temperatures together with sufficient ductility. It should be noted that ferritic steels with a similar microstructural design (bcc/B2) have been developed recently for hightemperature applications in power plants $[35,36]$. Therefore, it might be suggested that the bcc/B2 HEAs can also have a potential for

\footnotetext{
* Corresponding author. Laboratory of Bulk Nanostructured Materials, Belgorod State University, Pobeda 85, Belgorod, 308015, Russia.

E-mail addresses: stepanov@bsu.edu.ru, stepanov.nikita@icloud.com (N.D. Stepanov).
} 
practical applications. However, additional studies are required to develop alloys with the best combination of properties and to improve further their performance.

For instance, we have recently introduced the $\mathrm{Fe}_{36} \mathrm{Mn}_{21} \mathrm{Cr}_{18} \mathrm{Ni}_{15} \mathrm{Al}_{10}$ alloy with the bcc/B2 microstructure which maintains high strength at temperatures up to $400{ }^{\circ} \mathrm{C}[29,34]$. However at higher temperatures the strength of the alloy degraded considerably. An improvement of the high-temperature properties of the alloy is highly desirable. In this work, we have explored two possible options to increase the hightemperature strength of the alloy:

1. The replacement of Mn with Co could increase the melting temperature and improve the high-temperature strength because among the commonly used 3d transition metals, Co has a much higher melting temperature $\left(1495^{\circ} \mathrm{C}\right)$ in comparison to that of $\mathrm{Mn}$ $\left(1246^{\circ} \mathrm{C}\right)$.

2. An addition of $\mathrm{Ti}$ can improve the mechanical properties of the $\mathrm{Fe}_{36} \mathrm{Mn}_{21} \mathrm{Cr}_{18} \mathrm{Ni}_{15} \mathrm{Al}_{10}$ alloy because (i) Ti was suggested to benefit the stability of the bcc/B2 structure of the $\mathrm{Fe}_{36} \mathrm{Mn}_{21} \mathrm{Cr}_{18} \mathrm{Ni}_{15} \mathrm{Al}_{10}$ alloy [29] and (ii) Ti was found to have a positive effect on the hightemperature properties of steels with the bcc/B2 structure due to the formation of additional ordered phases [35,36].

Along these lines, structures and mechanical properties of the four non-equiatomic $\mathrm{Fe}$-(Co, Mn)-Cr-Ni-Al-(Ti) HEAs, namely the $\mathrm{Fe}_{36} \mathrm{Mn}_{21} \mathrm{Cr}_{18} \mathrm{Ni}_{15} \mathrm{Al}_{10}, \mathrm{Fe}_{36} \mathrm{Co}_{21} \mathrm{Cr}_{18} \mathrm{Ni}_{15} \mathrm{Al}_{10}, \mathrm{Fe}_{35} \mathrm{Mn}_{20} \mathrm{Cr}_{17} \mathrm{Ni}_{12} \mathrm{Al}_{12} \mathrm{Ti}_{4}$, and $\mathrm{Fe}_{35} \mathrm{Co}_{20} \mathrm{Cr}_{17} \mathrm{Ni}_{12} \mathrm{Al}_{12} \mathrm{Ti}_{4}$ alloys, are reported in this work. The exact compositions of the alloys were chosen based on preliminary screening of phase diagrams produced by the Thermo-Calc software; the objective was to maintain a solid solution matrix phase potentially strengthened by ordered precipitates. Two main aims were pursued: (i) to gain better understanding of the compositional effect on the structure and mechanical properties of the bcc-structured precipitationstrengthened HEAs; (ii) to establish ways of the high-temperature performance of such alloys improving.

\section{Materials and methods}

The alloys with nominal compositions of $\mathrm{Fe}_{36} \mathrm{Mn}_{21} \mathrm{Cr}_{18} \mathrm{Ni}_{15} \mathrm{Al}_{10}$, $\mathrm{Fe}_{36} \mathrm{Co}_{21} \mathrm{Cr}_{18} \mathrm{Ni}_{15} \mathrm{Al}_{10}, \quad \mathrm{Fe}_{35} \mathrm{Mn}_{20} \mathrm{Cr}_{17} \mathrm{Ni}_{12} \mathrm{Al}_{12} \mathrm{Ti}_{4}$, and $\mathrm{Fe}_{35} \mathrm{Co}_{20} \mathrm{Cr}_{17}$ $\mathrm{Ni}_{12} \mathrm{Al}_{12} \mathrm{Ti}_{4}$ (the subscripts indicate the atomic percentages (at. \%) of the corresponding elements) were produced by vacuum arc melting. High-purity (at least 99.9\%) powders of the constitutive elements were used as starting materials. The produced ingots had dimensions of $\sim 10 \times 12 \times 40 \mathrm{~mm}^{3}$. The ingots were remelted 5 times to ensure the chemical homogeneity. Specimens for microstructural characterization and mechanical testing were cut from the produced ingots using an electric discharge machine.

Microstructure and phase composition of the alloys in the as-cast condition were studied using X-ray diffraction (XRD), scanning (SEM) and transmission (TEM) electron microscopy techniques. XRD analysis was performed using a RIGAKU diffractometer and $\mathrm{Cu}$ Ka radiation. The obtained XRD patterns were used to measure the lattice parameters of the constitutive phases. Samples for SEM observations were prepared by careful mechanical polishing. SEM investigations were performed using a FEI Quanta 600 and a FEI Nova NanoSEM field emission gun (FEG) microscopes equipped with a back-scattered electron (BSE), an energy-dispersive X-ray spectrometry (EDS), and an electron backscattered diffraction (EBSD) detectors. EBSD phase maps were produced using a TSL OIM software. Samples for TEM analysis were prepared by the conventional twin-jet electro-polishing of mechanically pre-thinned to $100 \mu \mathrm{m}$ foils, in a mixture of $95 \% \mathrm{C}_{2} \mathrm{H}_{5} \mathrm{OH}$ and $5 \%$ $\mathrm{HClO}_{4}$ at the $27 \mathrm{~V}$ potential. TEM investigations were performed using a JEOL JEM-2100 microscope equipped with an EDS detector at an accelerating voltage of $200 \mathrm{kV}$. The volume fractions of different phases were measured from SEM-BSE/TEM bright-field images using a

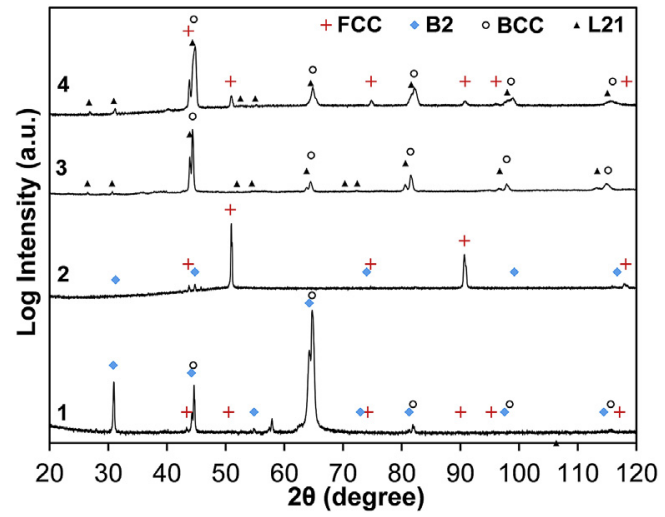

Fig. 1. $\mathrm{XRD}$ patterns of the $\mathrm{Fe}_{36} \mathrm{Mn}_{21} \mathrm{Cr}_{18} \mathrm{Ni}_{15} \mathrm{Al}_{10}$ (pattern \#1), $\mathrm{Fe}_{36} \mathrm{Co}_{21} \mathrm{Cr}_{18} \mathrm{Ni}_{15} \mathrm{Al}_{10} \quad$ (\#2), $\quad \mathrm{Fe}_{35} \mathrm{Mn}_{20} \mathrm{Cr}_{17} \mathrm{Ni}_{12} \mathrm{Al}_{12} \mathrm{Ti}_{4} \quad$ (\#3), and $\mathrm{Fe}_{35} \mathrm{Co}_{20} \mathrm{Cr}_{17} \mathrm{Ni}_{12} \mathrm{Al}_{12} \mathrm{Ti}_{4}$ (\#4) alloys in the as-cast conditions.

Digimizer Image Analysis Software.

Compression mechanical tests were performed on an Instron machine equipped with a radial heating furnace. Rectangular specimens of the alloys in the as-cast conditions with dimensions of $7 \times 5 \times 5 \mathrm{~mm}^{3}$ were used. The testing was carried out at room $\left(25^{\circ} \mathrm{C}\right)$ and elevated (400 or $600{ }^{\circ} \mathrm{C}$; additional testing at $800{ }^{\circ} \mathrm{C}$ was performed for the $\mathrm{Fe}_{35} \mathrm{Co}_{20} \mathrm{Cr}_{17} \mathrm{Ni}_{12} \mathrm{Al}_{12} \mathrm{Ti}_{4}$ alloy only) temperatures at an initial strain rate of $10^{-4} \mathrm{~s}^{-1}$ to $50 \%$ height reduction. Prior to the testing the specimens were placed in a preheated to the testing temperature furnace and held for $\approx 10 \mathrm{~min}$ to ensure working temperature which was controlled by a thermocouple attached to a side surface of the specimens.

Equilibrium phase diagrams were constructed using a Thermo-Calc (version 2017a) software employing a TCHEA2 (high-entropy alloys) database.

\section{Results}

\subsection{XRD analysis}

Fig. 1 shows XRD patterns of the experimental alloys in the as-cast condition; lattice parameters of the constitutive phases are summarized in Table 1. According to the XRD data, the $\mathbf{F e}_{36} \mathbf{M n}_{21} \mathbf{C r}_{18} \mathbf{N i}_{15} \mathbf{A l}_{10}$ alloy was composed of two principal phases -bcc and B2. The lattice parameters $(a)$ of the bcc and B2 phases were $2.878 \AA$ and $2.987 \AA$, respectively. In addition, tiny peaks from an fcc phase $(a=3.621 \AA$ ) can be seen. In contrast, the major phase of the $\mathbf{F e}_{36} \mathbf{C o}_{21} \mathbf{C r}_{18} \mathbf{N i}_{15} \mathbf{A l}_{10}$ alloy was the fcc one $(a=3.591 \AA)$. Additional small intensity maximums from the $\mathrm{B} 2$ phase $(\mathrm{a}=2.874 \AA)$ were also observed. The $\mathrm{Fe}_{35} \mathbf{M n}_{20} \mathrm{Cr}_{17} \mathrm{Ni}_{12} \mathrm{Al}_{12} \mathbf{T i}_{4}$ alloy was composed of two major phases: the bcc $\left(a=2.886 \AA\right.$ ) phase and an $\mathrm{L}_{1}$ (ordered fcc) phase ( $a=5.832 \AA$ ). The XRD pattern of the $\mathbf{F e}_{35} \mathbf{C o}_{20} \mathbf{C r}_{17} \mathbf{N i}_{12} \mathbf{A l}_{12} \mathbf{T i}_{4}$ alloy is quite similar to that of the previous alloy; yet in addition to the bcc and L2 1 peaks some reflections from the fcc phase ( $a=3.588 \AA$ ) were found.

Table 1

Lattice parameters of the constitutive phases of the $\mathrm{Fe}_{36} \mathrm{Mn}_{21} \mathrm{Cr}_{18} \mathrm{Ni}_{15} \mathrm{Al}_{10}$, $\mathrm{Fe}_{36} \mathrm{Co}_{21} \mathrm{Cr}_{18} \mathrm{Ni}_{15} \mathrm{Al}_{10}, \mathrm{Fe}_{35} \mathrm{Mn}_{20} \mathrm{Cr}_{17} \mathrm{Ni}_{12} \mathrm{Al}_{12} \mathrm{Ti}_{4}$, and $\mathrm{Fe}_{35} \mathrm{Co}_{20} \mathrm{Cr}_{17} \mathrm{Ni}_{12} \mathrm{Al}_{12} \mathrm{Ti}_{4}$ alloys in the as-cast conditions.

\begin{tabular}{|c|c|c|c|c|c|}
\hline \multirow[t]{2}{*}{ № } & \multirow[t]{2}{*}{ Alloy } & \multicolumn{4}{|c|}{ Lattice parameter, $\AA$} \\
\hline & & fcc & B2 & bcc & $\mathrm{L} 2_{1}$ \\
\hline 1 & $\mathrm{Fe}_{36} \mathrm{Mn}_{21} \mathrm{Cr}_{18} \mathrm{Ni}_{15} \mathrm{Al}_{10}$ & 3.621 & 2.897 & 2.878 & - \\
\hline 2 & $\mathrm{Fe}_{36} \mathrm{Co}_{21} \mathrm{Cr}_{18} \mathrm{Ni}_{15} \mathrm{Al}_{10}$ & 3.591 & 2.874 & - & - \\
\hline 3 & $\mathrm{Fe}_{35} \mathrm{Mn}_{20} \mathrm{Cr}_{17} \mathrm{Ni}_{12} \mathrm{Al}_{12} \mathrm{Ti}_{4}$ & - & - & 2.886 & 5.832 \\
\hline 4 & $\mathrm{Fe}_{35} \mathrm{Co}_{20} \mathrm{Cr}_{17} \mathrm{Ni}_{12} \mathrm{Al}_{12} \mathrm{Ti}_{4}$ & 3.588 & - & 2.887 & 5.734 \\
\hline
\end{tabular}




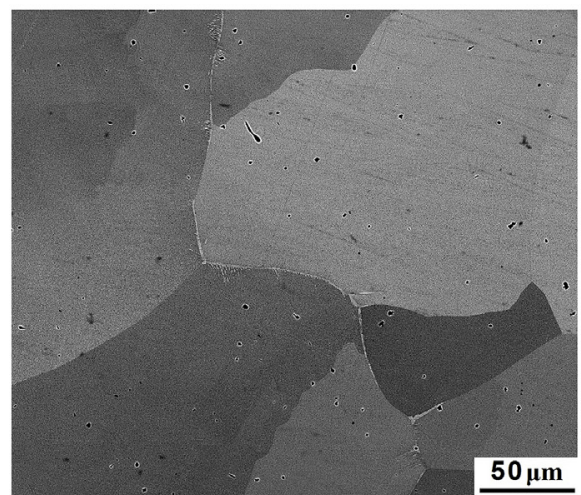

(a)

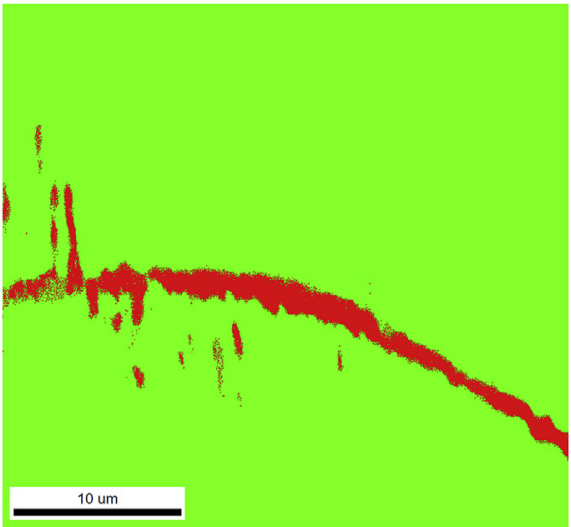

(c)

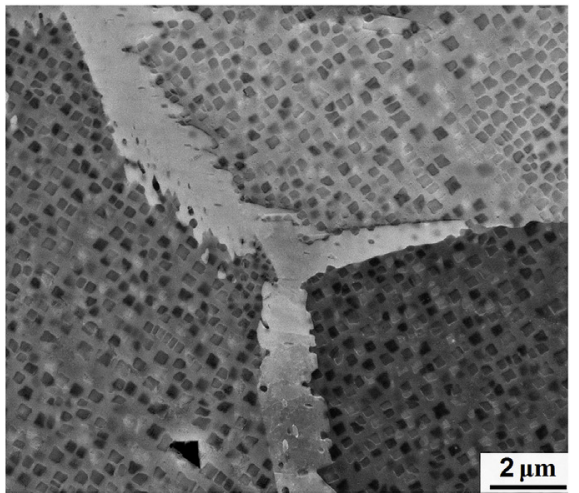

(b)

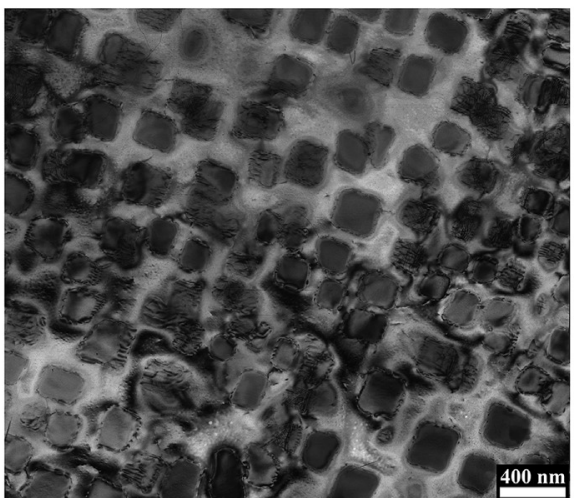

(d)

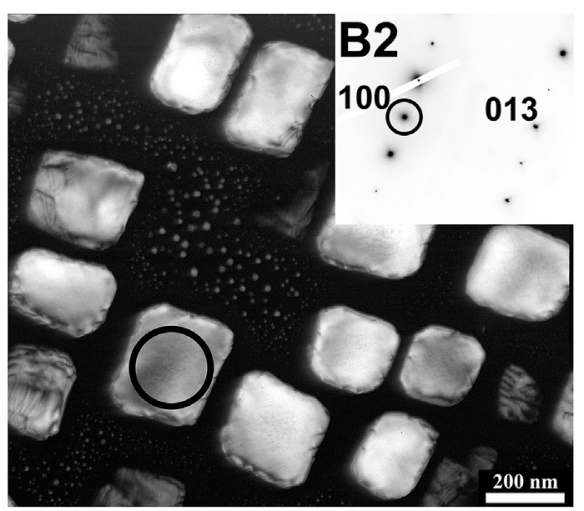

(e)

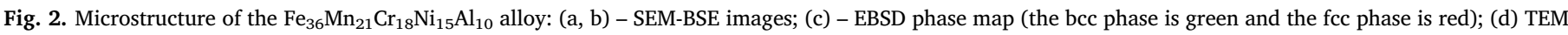

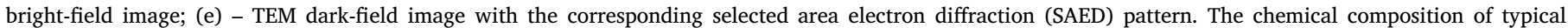

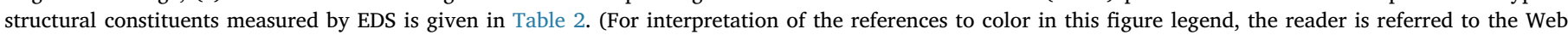
version of this article.)

\subsection{Microstructure}

The microstructure of the $\mathbf{F e}_{36} \mathbf{M n}_{\mathbf{2 1}} \mathbf{C r}_{\mathbf{1 8}} \mathbf{N i}_{\mathbf{1 5}} \mathbf{A l}_{\mathbf{1 0}}$ alloy is presented in Fig. 2. A low-magnification SEM-BSE image (Fig. 2a) showed apparently a single-phase structure with coarse $(d \approx 200 \mu \mathrm{m})$, irregularly shaped grains. The presence of many pores (fine black dots of irregular shape, some of them are indicated in Fig. 3a with arrows) should be noted; similar defects can be found in other alloys (Figs. 3a, 4a and 5a). At a higher magnification the presence of (i) discontinuous layer of the second phase with a thickness of several microns on the boundaries of coarse grains and (ii) cuboidal precipitates inside these grains can be observed (Fig. 2b). The grain boundary phase was enriched with Mn and Ni per SEM-EDS analysis (Table 2). EBSD phase map showed that those grains which contain precipitates have a bcc structure (red color in Fig. 2c) while the grain boundary phase had an fcc structure (green color in Fig. 2c). Note that the bcc and B2 phases cannot be distinguished from each other using the EBSD technique. The fraction of the fcc phase was found to be 0.03 . Some fcc particles nucleated at the boundary and then propagated into grain interiors. The precipitates inside the bcc grains were analyzed using TEM. The average size and fraction of the cuboidal precipitates were $240 \mathrm{~nm}$ and 0.38 , respectively. Selected area electron diffraction (SAED) patterns analysis has 


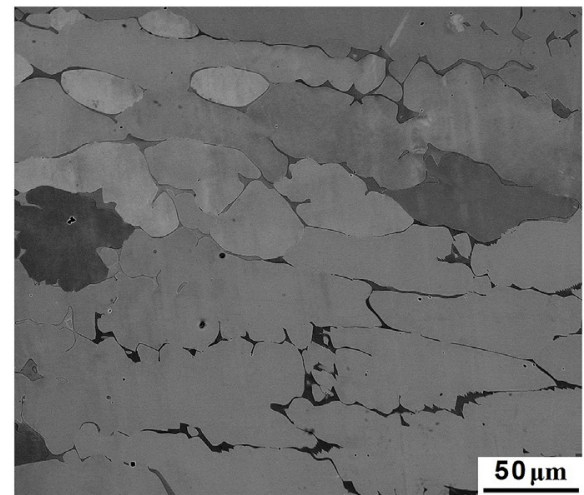

(a)

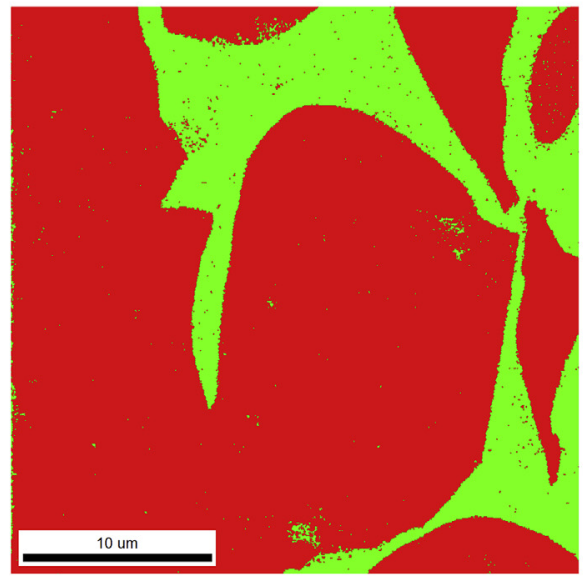

(c)

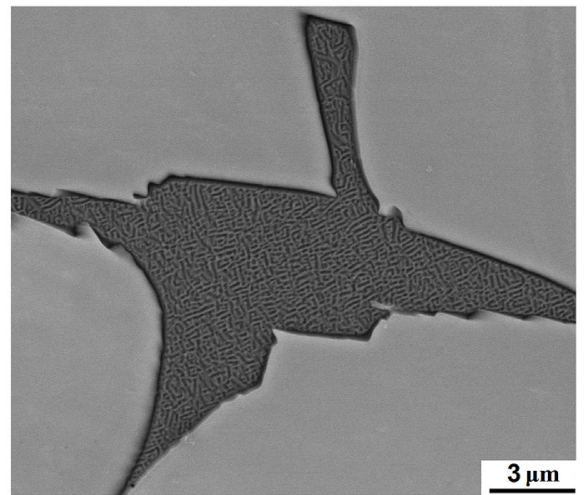

(b)

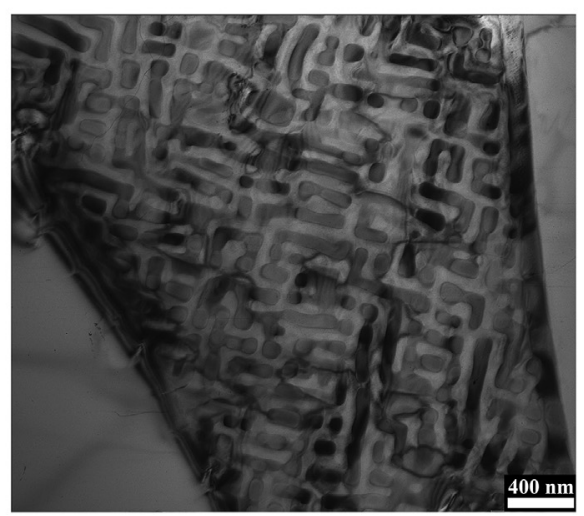

(d)

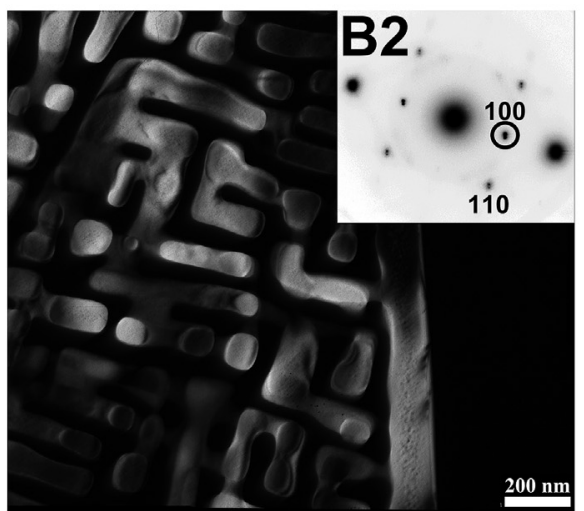

(e)

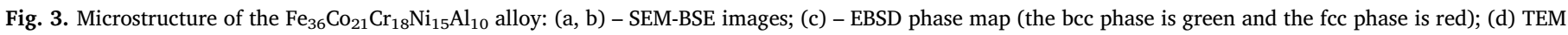

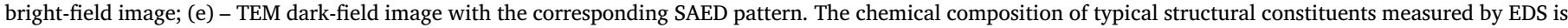
given in Table 3. (For interpretation of the references to color in this figure legend, the reader is referred to the Web version of this article.)

shown that the matrix had a disordered bcc structure, while the cuboidal precipitates had an ordered B2 structure (Fig. 2d). In addition to the relatively coarse cuboidal B2 precipitates, the bcc matrix also contains fine (the average size of $12 \mathrm{~nm}$ ) spherical precipitates. TEMEDS showed that the bcc matrix was enriched with $\mathrm{Fe}$ and $\mathrm{Cr}$ and depleted of $\mathrm{Ni}$ and $\mathrm{Al}$, while the $\mathrm{B} 2$ phase was enriched in $\mathrm{Ni}$ and $\mathrm{Al}$ and depleted of the rest of the elements (Table 2). The fine spherical B2 precipitates were too small to measure their chemical composition reliably.

At first glance the structure of the $\mathbf{F e}_{36} \mathbf{C o}_{21} \mathbf{C r}_{18} \mathbf{N i}_{15} \mathbf{A l}_{10}$ alloy (Fig. 3a) seems quite similar to that of the $\mathrm{Fe}_{36} \mathrm{Mn}_{21} \mathrm{Cr}_{18} \mathrm{Ni}_{15} \mathrm{Al}_{10}$ alloy (Fig. 2a): coarse, elongated grains with the second phase(s) along grain boundaries. Yet, the grain size was much smaller (thickness $\sim 50 \mu \mathrm{m}$ ), and the second phase fraction (a darker phase on the SEM-BSE image, Fig. 3a) was substantially higher -0.07 . Meanwhile, a higher magnification SEM-BSE image (Fig. 3b) showed that the matrix phase was free from any precipitates while the dark areas had a dual-phase basketwave-type structure, unlike the $\mathrm{Fe}_{36} \mathrm{Mn}_{21} \mathrm{Cr}_{18} \mathrm{Ni}_{15} \mathrm{Al}_{10}$ alloy. EBSD analysis revealed that the matrix phase had an fcc structure, while the second phase(s) (the dark areas on the SEM-BSE images) had a bccbased structure (Fig. 3c). The chemical composition of the fcc matrix was close to the nominal composition of the alloy (Table 3). TEM images (Fig. 3d and e) have confirmed the absence of any precipitates in the fcc matrix and the presence of a lamellar mixture of the bcc and 


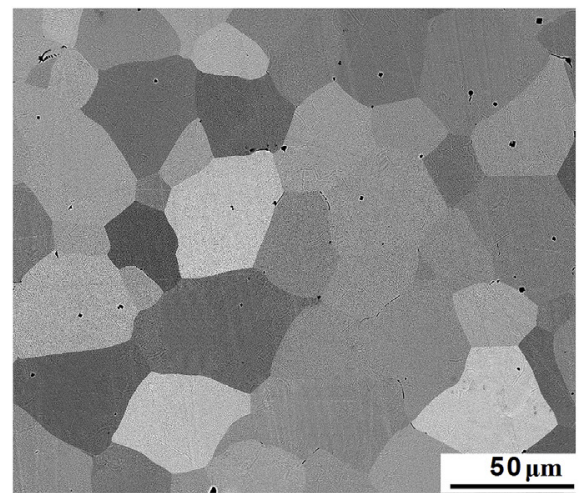

(a)

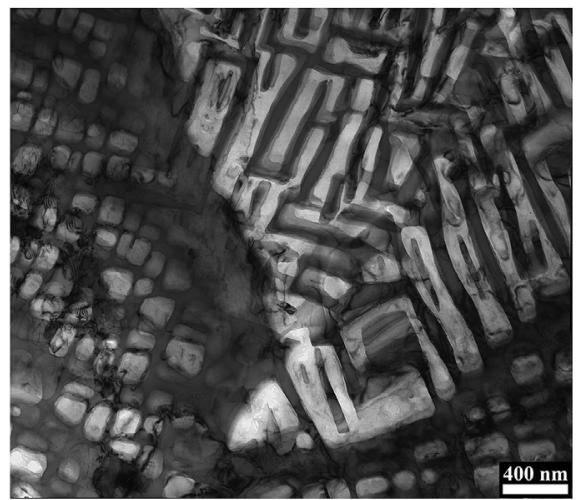

(c)

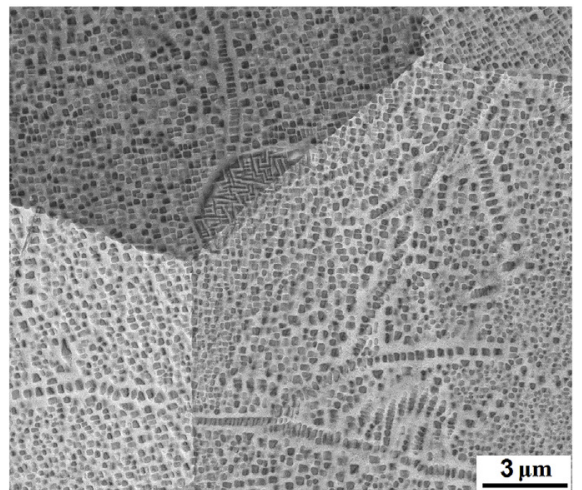

(b)

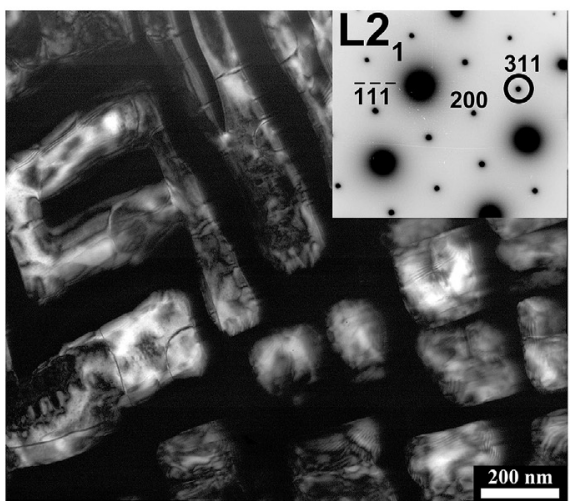

(d)

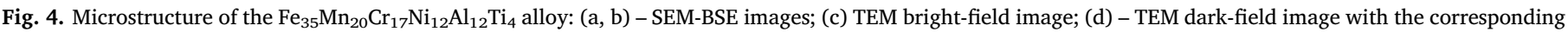
SAED pattern. The chemical composition of typical structural constituents measured by EDS is given in Table 3 .

B2 phases between the fcc grains. The volume fractions of both phases were almost identical: 0.03 of the bcc phase and 0.04 of the B2 phase. The average thickness of the bcc/B2 plates was $90 \mathrm{~nm}$. The bcc phase was enriched with $\mathrm{Fe}$ and $\mathrm{Cr}$, and the $\mathrm{B} 2$ phase - with $\mathrm{Ni}$ and $\mathrm{Al}$ (Table 3). Co was nearly evenly distributed between the two phases.

The microstructure of the $\mathbf{F e}_{35} \mathbf{M n}_{20} \mathbf{C r}_{17} \mathbf{N i}_{12} \mathbf{A l}_{12} \mathbf{T i}_{4}$ alloy on a lowmagnification SEM-BSE image was presented by equiaxed grains with the average size of $30 \mu \mathrm{m}$ (Fig. 4a). A higher magnification image demonstrated the presence of mostly cuboidal precipitates in the grains (Fig. 4b). Some of these cuboids were arranged in chains, forming celllike structures inside the grains. Also in some areas (e.g. the central part of Fig. 4b) a lamellar structure composed of plate-like particles of two types of phases was observed. Meanwhile EBSD analysis (not shown) has revealed the presence of a bcc phase(s) only. However, it should be noted that the $\mathrm{L} 2{ }_{1}$ phase detected by XRD (Fig. 1), cannot be reliably distinguished from the bcc (B2) phase(s) during EBSD scanning due to similar positions of many reflections. TEM images clearly illustrated that the cuboidal precipitates inside the disordered bcc matrix had an L2 1 ordered structure (Fig. 4d). The average size of the cuboidal L2 1 precipitates was $190 \mathrm{~nm}$. The modulated lamellar structure was also composed of the bcc and $\mathrm{L} 22_{1}$ phases in form of plates; the thickness of plates was $\sim 70-200 \mathrm{~nm}$. The volume fraction of the $\mathrm{L} 2_{1}$ phase was 0.42 . The majority of the bcc matrix was enriched with $\mathrm{Fe}$ and $\mathrm{Cr}$, while the cuboidal $\mathrm{L}_{1}$ precipitates were mostly composed of $\mathrm{Ni}, \mathrm{Al}$, and $\mathrm{Ti}$ (Table 4). However, the bcc plates that formed the modulated structure had a quite similar chemical composition with the cuboidal $\mathrm{L} 2_{1}$ particles. The plate-like $\mathrm{L} 2{ }_{1}$ particles, in turn, had less $\mathrm{Fe}$ and $\mathrm{Cr}$ and more $\mathrm{Ni}, \mathrm{Al}$, and $\mathrm{Ti}$ than their cuboidal counterparts.

The $\mathbf{F e}_{35} \mathbf{C o}_{20} \mathrm{Cr}_{17} \mathbf{N i}_{12} \mathrm{Al}_{12} \mathrm{Ti}_{4}$ alloy had the most complex microstructure among the studied alloys (Fig. 5). The structure consisted of grains with the average size of $65 \mu \mathrm{m}$ (Fig. 5a). A thin layer of a second phase was found along grain boundaries (a light phase on the SEM-BSE images). Lens-shaped areas expanded from the boundaries into grains interior. Also, colonies of lamellar precipitates with a light contrast were observed within the grains (Fig. 5b). The EBSD phase map (Fig. 5c) clearly showed that the grain boundary phase, as well as the lens-shaped areas, had mostly an fcc structure. A TEM bright-field image illustrated the lamellar structure inside the most of the grains (Fig. 5d); this structure was composed mainly of the bcc and L2 1 plates (Fig. 5e). The average thickness of these plates was $65 \mathrm{~nm}$, and the fractions of the bcc and $\mathrm{L} 2_{1}$ phases were 0.44 and 0.39 , respectively. In addition, some lamellae of the fcc phase were found; they are marked with arrows in Fig. 5d and showed in a dark-field image (Fig. 5f). The fraction of the fcc phase was 0.17 . Chemical analysis showed that the bcc phase had a composition close to that of the alloy, while the $\mathrm{L} 2{ }_{1}$ particles were enriched with $\mathrm{Ni}, \mathrm{Al}$, and $\mathrm{Ti}$, and depleted of $\mathrm{Fe}$ and $\mathrm{Cr}$ (Table 5). The fcc particles were enriched with Fe.

\subsection{Mechanical properties}

Fig. 6 presents stress-strain curves, obtained during compression testing of the $\mathrm{Fe}_{36} \mathrm{Mn}_{21} \mathrm{Cr}_{18} \mathrm{Ni}_{15} \mathrm{Al}_{10}$ (Fig. 6a), $\mathrm{Fe}_{36} \mathrm{Co}_{21} \mathrm{Cr}_{18} \mathrm{Ni}_{15} \mathrm{Al}_{10}$ (Fig. 6b), $\mathrm{Fe}_{35} \mathrm{Mn}_{20} \mathrm{Cr}_{17} \mathrm{Ni}_{12} \mathrm{Al}_{12} \mathrm{Ti}_{4}$ (Fig. 6c), and $\mathrm{Fe}_{35} \mathrm{Co}_{20} \mathrm{Cr}_{17} \mathrm{Ni}_{12} \mathrm{Al}_{12} \mathrm{Ti}_{4}$ (Fig. 6d) alloys at room temperature, $400{ }^{\circ} \mathrm{C}$, $600{ }^{\circ} \mathrm{C}$, and $800{ }^{\circ} \mathrm{C}$ (the latter for the $\mathrm{Fe}_{35} \mathrm{Co}_{20} \mathrm{Cr}_{17} \mathrm{Ni}_{12} \mathrm{Al}_{12} \mathrm{Ti}_{4}$ alloy only). The yield strength and deformation to fracture of the alloys are summarized in Table 6. Apparently, the variations in chemical composition had a significant effect on the mechanical behavior of the alloys.

The $\mathbf{F e}_{36} \mathbf{M n}_{21} \mathbf{C r}_{18} \mathbf{N i}_{15} \mathrm{Al}_{10}$ alloy had rather high yield strength of $910 \mathrm{MPa}$ at room temperature (Table 6); after the yielding the alloy showed continuous strengthening (Fig. 6a). The alloy also had good 


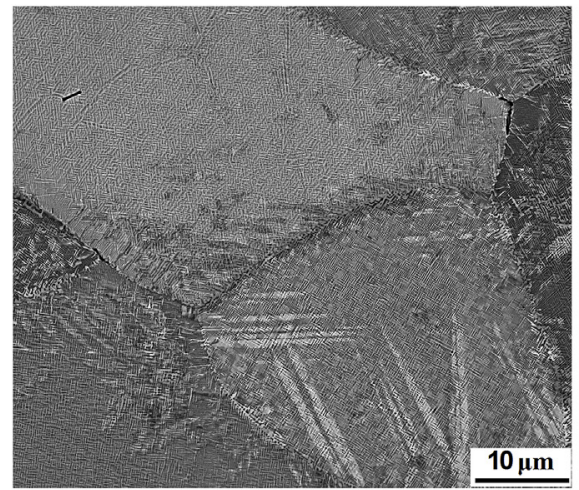

(a)

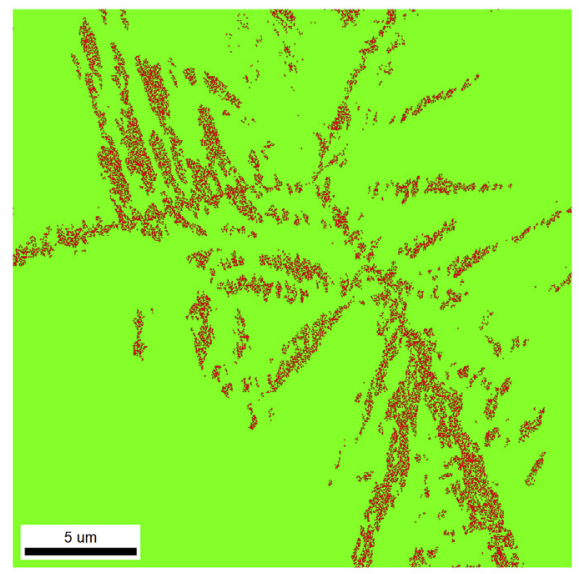

(c)

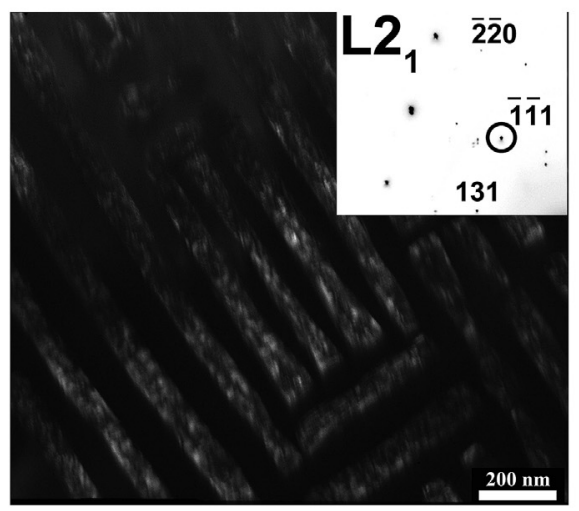

(e)

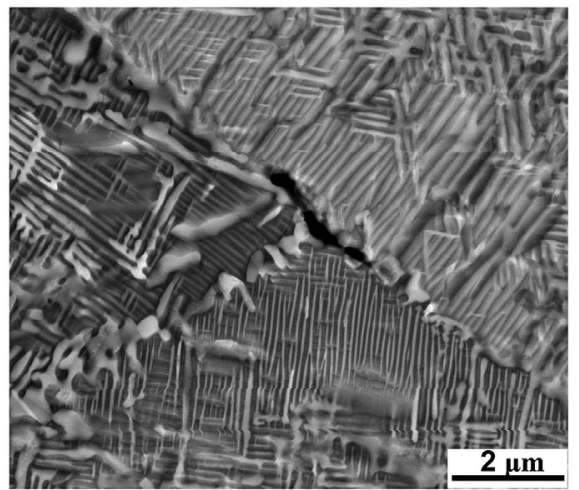

(b)

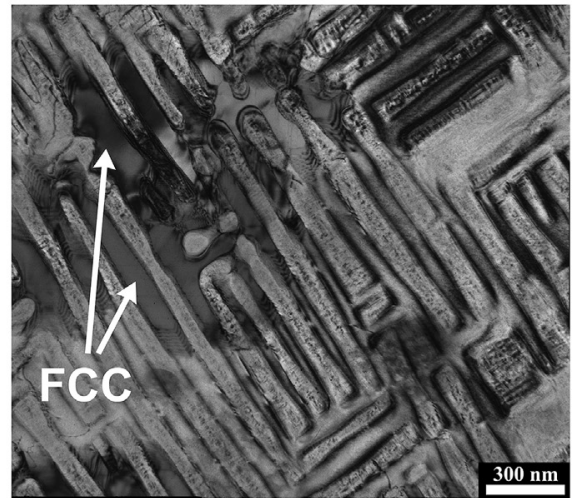

(d)

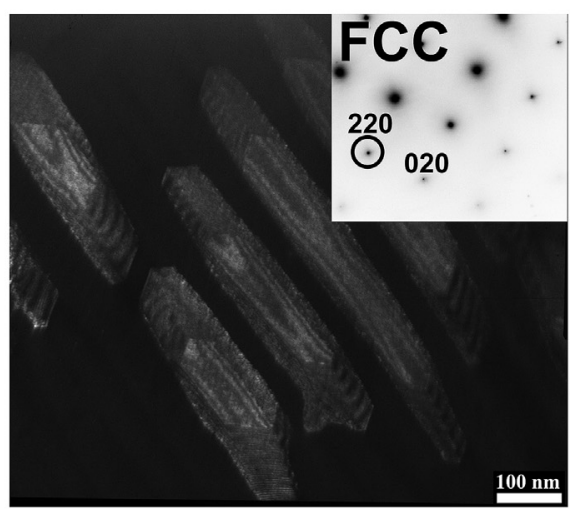

(f)

Fig. 5. Microstructure of the $\mathrm{Fe}_{35} \mathrm{Co}_{20} \mathrm{Cr}_{17} \mathrm{Ni}_{12} \mathrm{Al}_{12} \mathrm{Ti}_{4}$ alloy: (a, b) - SEM-BSE images; (c) - EBSD phase map (the bcc phase is green and the fcc phase is red); (d) TEM bright-field image; (e, f) - TEM dark-field images with the corresponding SAED patterns. The chemical composition of typical structural constituents measured by EDS is given in Table 5. (For interpretation of the references to color in this figure legend, the reader is referred to the Web version of this article.)

Table 2

Chemical composition (in at.\%) of the structural constituents of the $\mathrm{Fe}_{36} \mathrm{Mn}_{21} \mathrm{Cr}_{18} \mathrm{Ni}_{15} \mathrm{Al}_{10}$ alloy measured by SEM/TEM-based EDS.

\begin{tabular}{llllllll}
\hline Constituent & $\mathrm{Fe}$ & $\mathrm{Co}$ & $\mathrm{Mn}$ & $\mathrm{Cr}$ & $\mathrm{Ni}$ & $\mathrm{Al}$ & $\mathrm{Ti}$ \\
\hline bcc & 45.6 & - & 18.7 & 26.3 & 5.9 & 3.5 & - \\
B2 & 29.2 & - & 12.5 & 15.7 & 25.0 & 17.6 & - \\
fcc & 36.3 & - & 21.2 & 15.6 & 17.6 & 9.3 & - \\
Actual composition of the alloy & 36.4 & - & 19.1 & 18.7 & 15.4 & 10.4 & -
\end{tabular}

Table 3

Chemical composition (in at.\%) of the structural constituents of the $\mathrm{Fe}_{36} \mathrm{Co}_{21} \mathrm{Cr}_{18} \mathrm{Ni}_{15} \mathrm{Al}_{10}$ alloy measured by SEM/TEM-based EDS.

\begin{tabular}{lllllllll}
\hline Constituent & $\mathrm{Fe}$ & $\mathrm{Co}$ & $\mathrm{Mn}$ & $\mathrm{Cr}$ & $\mathrm{Ni}$ & $\mathrm{Al}$ & $\mathrm{Ti}$ \\
\hline fcc & 35.2 & 21.1 & - & 18.4 & 14.7 & 10.6 & - \\
bcc & 38.2 & 18.1 & - & 29.3 & 8.1 & 6.3 & - \\
B2 & 25.9 & 20.0 & - & 14.1 & 19.2 & 20.7 & - \\
Actual composition of the alloy & 35.9 & 20.5 & - & 18.2 & 14.7 & 10.7 & -
\end{tabular}


Table 4

Chemical composition (in at.\%) of the structural constituents of the $\mathrm{Fe}_{35} \mathrm{Mn}_{20} \mathrm{Cr}_{17} \mathrm{Ni}_{12} \mathrm{Al}_{12} \mathrm{Ti}_{4}$ alloy measured by SEM/TEM-based EDS

\begin{tabular}{lccccccc}
\hline Constituent & $\mathrm{Fe}$ & $\mathrm{Co}$ & $\mathrm{Mn}$ & $\mathrm{Cr}$ & $\mathrm{Ni}$ & $\mathrm{Al}$ & $\mathrm{Ti}$ \\
\hline Matrix bcc & 38.9 & - & 20.3 & 20.6 & 8.9 & 8.2 & 3.2 \\
Cuboidal L2 & 31.8 & - & 18.0 & 13.1 & 17.7 & 13.5 & 5.8 \\
Plate-like bcc & 30.7 & - & 18.2 & 14.8 & 17.7 & 12.7 & 5.8 \\
Plate-like L2 & 26.4 & - & 16.1 & 11.1 & 23.3 & 15.7 & 7.5 \\
Actual composition of the alloy & 35.0 & - & 19.5 & 17.2 & 12.0 & 12.1 & 4.1 \\
\hline
\end{tabular}

Table 5

Chemical composition (in at.\%) of the structural constituents of the $\mathrm{Fe}_{35} \mathrm{Co}_{20} \mathrm{Cr}_{17} \mathrm{Ni}_{12} \mathrm{Al}_{12} \mathrm{Ti}_{4}$ alloy measured by SEM/TEM-based EDS.

\begin{tabular}{lllllllll}
\hline Constituent & $\mathrm{Fe}$ & $\mathrm{Co}$ & $\mathrm{Mn}$ & $\mathrm{Cr}$ & $\mathrm{Ni}$ & $\mathrm{Al}$ & $\mathrm{Ti}$ \\
\hline bcc & 33.0 & 19.2 & - & 21.1 & 9.4 & 12.5 & 4.8 \\
L2 1 & 23.1 & 22.5 & - & 10.4 & 17.5 & 18.4 & 8.1 \\
fcc & 42.1 & 18.9 & - & 18.6 & 11.9 & 6.7 & 1.8 \\
Actual composition of the alloy & 35.0 & 19.5 & - & 17.0 & 11.6 & 13.2 & 3.7 \\
\hline
\end{tabular}

ductility not fracturing after $50 \%$ of compression deformation at all testing temperatures. An increase in the testing temperature to $400{ }^{\circ} \mathrm{C}$ resulted in a moderate decrease in the yield strength and somewhat reduced work hardening. Further increase of the testing temperature to $600{ }^{\circ} \mathrm{C}$ has resulted in a pronounced drop of the yield strength to $325 \mathrm{MPa}$. Also, after the yielding the alloy exhibited a very short work hardening stage followed by a steady state flow stage.

The $\mathbf{F e}_{\mathbf{3 6}} \mathbf{C o}_{\mathbf{2 1}} \mathbf{C r}_{\mathbf{1 8}} \mathbf{N i}_{\mathbf{1 5}} \mathbf{A l}_{\mathbf{1 0}}$ alloy was much softer than the $\mathrm{Fe}_{36} \mathrm{Mn}_{21} \mathrm{Cr}_{18} \mathrm{Ni}_{15} \mathrm{Al}_{10}$ alloy (Fig. 6b, Table 6). For instance, the yield strength of the $\mathrm{Fe}_{36} \mathrm{Co}_{21} \mathrm{Cr}_{18} \mathrm{Ni}_{15} \mathrm{Al}_{10}$ alloy at room temperature was only $250 \mathrm{MPa}$. However, the alloy showed a very good strain hardening capacity; its flow stress approached $1000 \mathrm{MPa}$ after $30 \%$ height

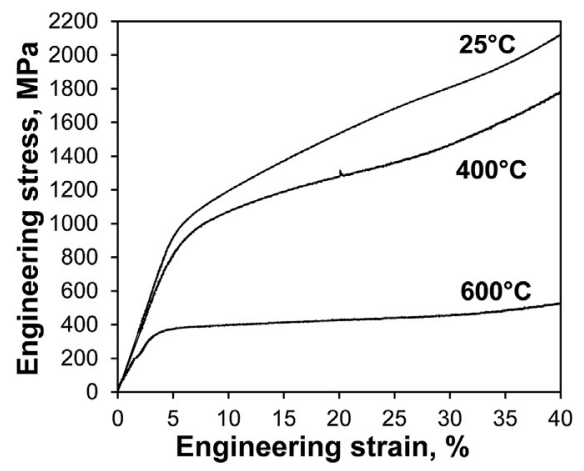

(a)

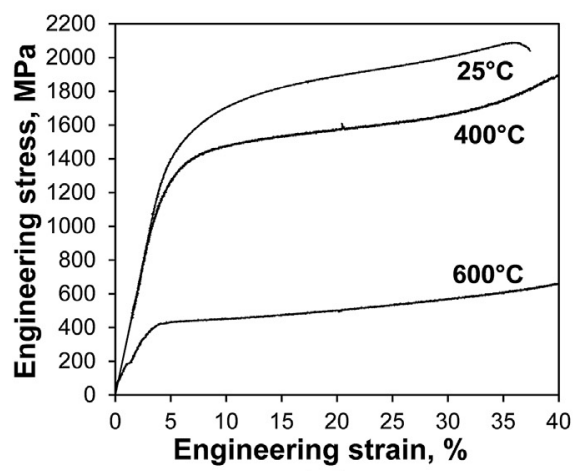

(c) reduction. The alloy was also very ductile ( $>50 \%$ without fracture) at all testing temperatures. An increase in temperature to $400{ }^{\circ} \mathrm{C}$ and $600^{\circ} \mathrm{C}$ had resulted in some decrease in the yield strength to $155 \mathrm{MPa}$ and $150 \mathrm{MPa}$, respectively. The strain hardening rate also diminished slightly with the temperature increase.

The mechanical behavior of the $\mathbf{F e}_{35} \mathbf{M n}_{20} \mathbf{C r}_{17} \mathbf{N i}_{12} \mathbf{A l}_{12} \mathbf{T i}_{4}$ alloy was quite similar to that of the $\mathrm{Fe}_{36} \mathrm{Mn}_{21} \mathrm{Cr}_{18} \mathrm{Ni}_{15} \mathrm{Al}_{10}$ alloy (Fig. $6 \mathrm{c}$, Table 6). In terms of the yield strength, the Ti-containing alloy was stronger at all testing temperatures. For example, the yield strength of the alloy was $1240 \mathrm{MPa}, 1100 \mathrm{MPa}$, and $355 \mathrm{MPa}$ at room temperature, $400{ }^{\circ} \mathrm{C}$ and $600{ }^{\circ} \mathrm{C}$, respectively. Yet, the alloy showed a less pronounced strain hardening at all temperatures. At room temperature, the alloy fractured after $31 \%$ height reduction. An increase in temperature improved ductility since the alloy had not fractured after $50 \%$ reduction at $400{ }^{\circ} \mathrm{C}$ and $600{ }^{\circ} \mathrm{C}$.

Finally, the $\mathrm{Fe}_{35} \mathrm{Co}_{20} \mathrm{Cr}_{17} \mathrm{Ni}_{12} \mathrm{Al}_{12} \mathrm{Ti}_{4}$ turned out to be the strongest among the tested alloys (Fig. $6 \mathrm{~d}$, Table 6). It had the yield strength of $1420 \mathrm{MPa}$ and $1285 \mathrm{MPa}$ at room temperature and $400{ }^{\circ} \mathrm{C}$, respectively. What is even more important, the alloy had a high yield strength of $785 \mathrm{MPa}$ at $600{ }^{\circ} \mathrm{C}$. However testing at $800{ }^{\circ} \mathrm{C}$ has revealed a drop in strength to $190 \mathrm{MPa}$. At room temperature and $400{ }^{\circ} \mathrm{C}$ the alloy exhibited a prolonged hardening stage after the yielding, but had rather limited ductility: $18 \%$ and $24 \%$, respectively. At higher temperatures a steady state flow stage was observed till $50 \%$ strain.

\subsection{Phase diagrams}

Equilibrium phase diagrams (dependencies of the fractions of the constitutive phase on temperature) of the studied alloys are shown in Fig. 7. Characteristic phase transformation temperatures are summarized in Table 7. The $\mathbf{F e}_{\mathbf{3 6}} \mathbf{M n}_{\mathbf{2 1}} \mathbf{C r}_{\mathbf{1 8}} \mathbf{N i}_{\mathbf{1 5}} \mathbf{A l}_{\mathbf{1 0}}$ alloy was expected to start the solidification with the single bcc phase (as well as the rest of the alloys) (Fig. 7a); the predicted liquidus and solidus temperatures were

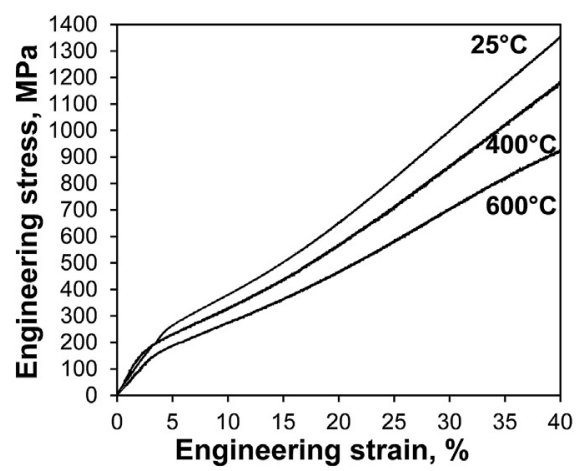

(b)

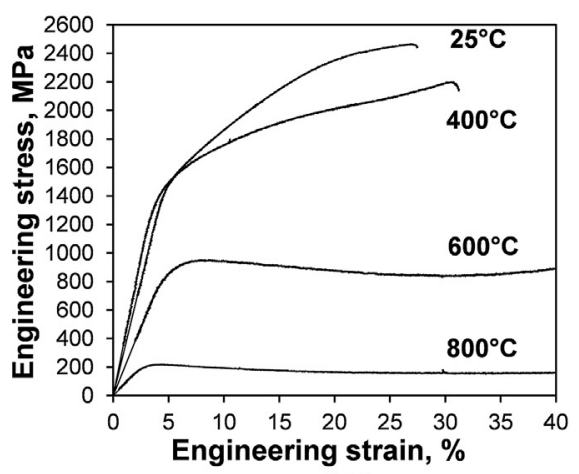

(d)

Fig. 6. Compression stress-strain curves at different temperatures of: (a) $\mathrm{Fe}_{36} \mathrm{Mn}_{21} \mathrm{Cr}_{18} \mathrm{Ni}_{15} \mathrm{Al}_{10}$ alloy; (b) $\mathrm{Fe}_{36} \mathrm{Co}_{21} \mathrm{Cr}_{18} \mathrm{Ni}_{15} \mathrm{Al}_{10}$ alloy; (c) $\mathrm{Fe}_{35} \mathrm{Mn}_{20} \mathrm{Cr}_{17} \mathrm{Ni}_{12} \mathrm{Al}_{12} \mathrm{Ti}_{4}$ alloy; (d) $\mathrm{Fe}_{35} \mathrm{Co}_{20} \mathrm{Cr}_{17} \mathrm{Ni}_{12} \mathrm{Al}_{12} \mathrm{Ti}_{4}$ alloy. 
Table 6

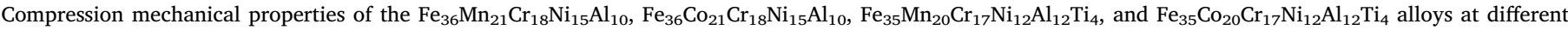
temperatures.

\begin{tabular}{|c|c|c|c|c|c|c|c|c|}
\hline \multirow[t]{2}{*}{$\mathrm{T},{ }^{\circ} \mathrm{C}$} & \multicolumn{2}{|c|}{$\mathrm{Fe}_{36} \mathrm{Mn}_{21} \mathrm{Cr}_{18} \mathrm{Ni}_{15} \mathrm{Al}_{10}$} & \multicolumn{2}{|c|}{$\mathrm{Fe}_{36} \mathrm{Co}_{21} \mathrm{Cr}_{18} \mathrm{Ni}_{15} \mathrm{Al}_{10}$} & \multicolumn{2}{|c|}{$\mathrm{Fe}_{35} \mathrm{Mn}_{20} \mathrm{Cr}_{17} \mathrm{Ni}_{12} \mathrm{Al}_{12} \mathrm{Ti}_{4}$} & \multicolumn{2}{|c|}{$\mathrm{Fe}_{35} \mathrm{Co}_{20} \mathrm{Cr}_{17} \mathrm{Ni}_{12} \mathrm{Al}_{12} \mathrm{Ti}_{4}$} \\
\hline & $\sigma_{0.2}, \mathrm{MPa}$ & $\varepsilon_{\mathrm{f}}, \%$ & $\sigma_{0.2}, \mathrm{MPa}$ & $\varepsilon_{\mathrm{f}}, \%$ & $\sigma_{0.2}, \mathrm{MPa}$ & $\varepsilon_{\mathrm{f}}, \%$ & $\sigma_{0.2}, \mathrm{MPa}$ & $\varepsilon_{\mathrm{f}}, \%$ \\
\hline 25 & 910 & $>50$ & 250 & $>50$ & 1280 & 31 & 1420 & 18 \\
\hline 400 & 755 & $>50$ & 155 & $>50$ & 1100 & $>50$ & 1285 & 24 \\
\hline 600 & 325 & $>50$ & 150 & $>50$ & 355 & $>50$ & 795 & $>50$ \\
\hline 800 & - & - & - & - & - & - & 285 & $>50$ \\
\hline
\end{tabular}

$1577^{\circ} \mathrm{C}$ and $1432^{\circ} \mathrm{C}$, respectively (Table 7). After a prolonged single bcc phase field, the $\mathrm{B} 2$ phase was expected to precipitate at $1131{ }^{\circ} \mathrm{C}$. At slightly lower temperatures of $1058^{\circ} \mathrm{C}$ and $1019^{\circ} \mathrm{C}$ respectively the fcc and sigma phases appeared. The fractions of the B2, fcc, and sigma phases increased pronouncedly and at $914{ }^{\circ} \mathrm{C}$ the bcc phase disappeared. The B2 phase was enriched with $\mathrm{Ni}$ and $\mathrm{Al}$, the fcc phase with $\mathrm{Fe}$, and the sigma phase - with $\mathrm{Cr}$ and $\mathrm{Mn}$. Note that some differences can be found in the current phase diagram in comparison to that reported in Ref. [29] for the same alloy; this is due to different versions of thermodynamic databases used for the calculations.

The $\mathbf{F e}_{36} \mathbf{C o}_{21} \mathbf{C r}_{18} \mathbf{N i}_{15} \mathbf{A l}_{10}$ alloy phase diagram (Fig. $7 \mathrm{~b}$ ) was distinctively different from that of the $\mathrm{Fe}_{36} \mathrm{Mn}_{21} \mathrm{Cr}_{18} \mathrm{Ni}_{15} \mathrm{Al}_{10}$ alloy (Fig. 7a). First, the solidification started at a lower temperature and the solidification range was narrower - the liquidus and solidus temperatures were $1385{ }^{\circ} \mathrm{C}$ and $1355^{\circ} \mathrm{C}$ respectively (Table 7). The solidification started from the bcc phase, yet the fcc phase also appeared from the liquid at temperatures below $1371{ }^{\circ} \mathrm{C}$. As a result, the solidification terminated with a mixture of the bcc and fcc phases with the fractions of 0.64 and 0.36 respectively. However, the fcc phase fraction quickly increased with a further decrease of temperature to $\sim 1200{ }^{\circ} \mathrm{C}$. In addition, the ordered B2 phase appeared at temperatures below $1287^{\circ} \mathrm{C}$. As the result, the bcc phase disappeared at $1213{ }^{\circ} \mathrm{C}$. In a high-temperature $(\mathrm{bcc}+\mathrm{fcc})$ region, both the bcc and fcc phases had the chemical compositions close to the nominal composition of the alloy. In turn, in a lower temperature (fcc $+\mathrm{B} 2$ ) region the B2 phase was enriched with $\mathrm{Al}$ and $\mathrm{Ni}$, while the fcc phase was mostly composed of $\mathrm{Fe}$ and $\mathrm{Cr}$. Co was nearly evenly distributed between the phases.

The predicted phase diagram of the $\mathbf{F e}_{35} \mathbf{M n}_{20} \mathbf{C r}_{17} \mathbf{N i}_{12} \mathbf{A l}_{12} \mathbf{T i}_{4}$ alloy (Fig. 7c) looks very close to that of the $\mathrm{Fe}_{36} \mathrm{Mn}_{21} \mathrm{Cr}_{18} \mathrm{Ni}_{15} \mathrm{Al}_{10}$ alloy (Fig. 7a). The liquidus solidus and solvus temperatures of the $\mathrm{B} 2$ and sigma phases of both alloys were quite similar (Table 7). Yet, the solvus temperature of the fcc phase in the Ti-containing alloy was much lower $\left(834^{\circ} \mathrm{C}\right)$, and the fcc phase was expected to have the ordered $\mathrm{L}_{2}$ structure. Almost simultaneously with the $\mathrm{L} 1_{2}$ fcc a Laves phase with a hexagonal (C14) lattice appeared (the corresponding solvus temperature is $840^{\circ} \mathrm{C}$ ). The Laves phase had a composition close to that of a binary $\mathrm{Fe}_{2} \mathrm{Ti}$ compound, while the composition of the $\mathrm{L} 1_{2}$ fcc phase was close to $\mathrm{Ni}_{50} \mathrm{Al}_{30} \mathrm{Ti}_{20}$.

Finally, the phase diagram of the $\mathbf{F e}_{35} \mathbf{C o}_{20} \mathbf{C r}_{17} \mathbf{N i}_{12} \mathbf{A l}_{12} \mathbf{T i}_{4}$ alloy (Fig. 7d) is rather similar to that of the $\mathrm{Fe}_{36} \mathrm{Co}_{21} \mathrm{Cr}_{18} \mathrm{Ni}_{15} \mathrm{Al}_{10}$ alloy (Fig. 7b), yet some differences can be found. For instance, a solidification range of this Ti-containing alloy was rather wide; the liquidus and solidus temperatures were $1345^{\circ} \mathrm{C}$ and $1216^{\circ} \mathrm{C}$, respectively (Table 7). Although the solidification started from the disordered bcc phase, both the B2 and fcc phases formed during solidification, and the B2 one appeared first. When the solidification terminated, the alloy was composed of three phases: bcc, fcc, and B2. The fcc and B2 phases were the principal phases with the fractions of $\sim 0.40-0.55$ at temperatures

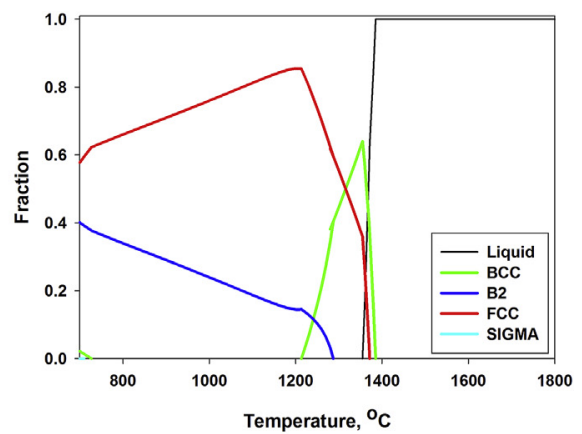

(b)

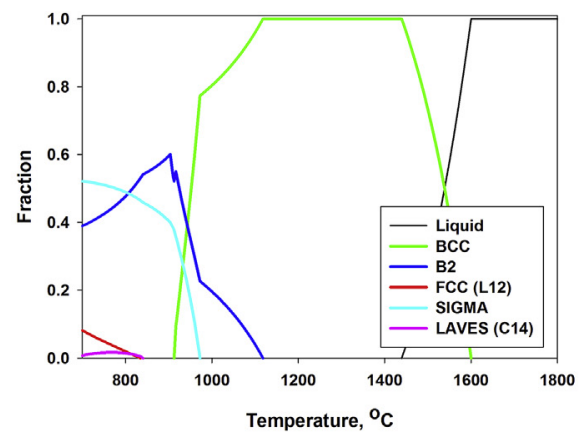

(c)

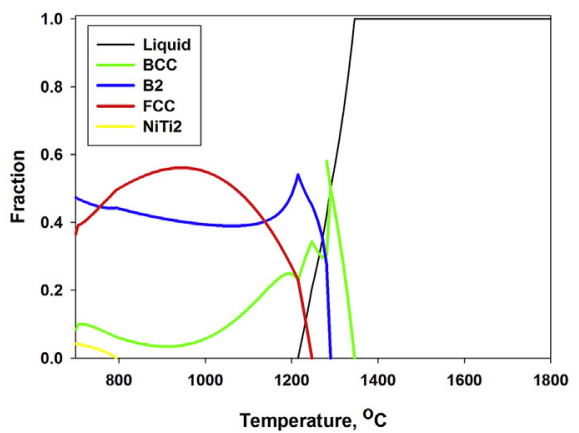

(d)

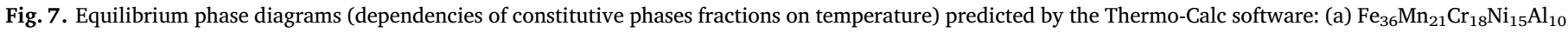
alloy; (b) $\mathrm{Fe}_{36} \mathrm{Co}_{21} \mathrm{Cr}_{18} \mathrm{Ni}_{15} \mathrm{Al}_{10}$ alloy; (c) $\mathrm{Fe}_{35} \mathrm{Mn}_{20} \mathrm{Cr}_{17} \mathrm{Ni}_{12} \mathrm{Al}_{12} \mathrm{Ti}_{4}$ alloy; (d) $\mathrm{Fe}_{35} \mathrm{Co}_{20} \mathrm{Cr}_{17} \mathrm{Ni}_{12} \mathrm{Al}_{12} \mathrm{Ti}_{4}$ alloy. 
Table 7

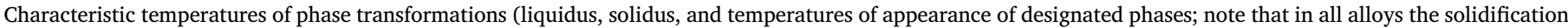

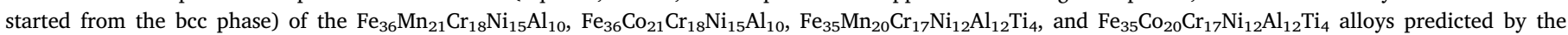
Thermo-Calc software.

\begin{tabular}{|c|c|c|c|c|}
\hline $\mathrm{T},{ }^{\circ} \mathrm{C}$ & $\mathrm{Fe}_{36} \mathrm{Mn}_{21} \mathrm{Cr}_{18} \mathrm{Ni}_{15} \mathrm{Al}_{10}$ & $\mathrm{Fe}_{36} \mathrm{Co}_{21} \mathrm{Cr}_{18} \mathrm{Ni}_{15} \mathrm{Al}_{10}$ & $\mathrm{Fe}_{35} \mathrm{Mn}_{20} \mathrm{Cr}_{17} \mathrm{Ni}_{12} \mathrm{Al}_{12} \mathrm{Ti}_{4}$ & $\mathrm{Fe}_{35} \mathrm{Co}_{20} \mathrm{Cr}_{17} \mathrm{Ni}_{12} \mathrm{Al}_{12} \mathrm{Ti}_{4}$ \\
\hline Liquidus & 1577 & 1385 & 1600 & 1346 \\
\hline Solidus & 1432 & 1355 & 1440 & 1215 \\
\hline B2 & 1131 & 1287 & 1118 & 1290 \\
\hline FCC & 1058 & 1371 & 834 & 1247 \\
\hline Sigma & 1019 & 710 & 972 & - \\
\hline Laves & - & - & 840 & - \\
\hline NiTi2 & - & - & - & 794 \\
\hline
\end{tabular}

below $1150^{\circ} \mathrm{C}$ while the bcc phase was a minor one with the fraction of $<0.15$. Another minor phase, $\mathrm{NiTi}_{2}$ appeared at temperatures below $794^{\circ} \mathrm{C}$. The bcc phase was enriched with $\mathrm{Fe}$ and $\mathrm{Cr}$, the B2 phase - with $\mathrm{Ni}, \mathrm{Al}$, and $\mathrm{Ti}$, while the fcc phase - with Fe. Co was rather homogeneously distributed between the three phases. The $\mathrm{NiTi}_{2}$ phase composition was close to the following formula ( $\mathrm{Co}, \mathrm{Cr}, \mathrm{Ni}_{1} \mathrm{Ti}_{1}$ with almost even percentages of $\mathrm{Co}, \mathrm{Cr}$, and Ni.

\section{Discussion}

The present study has revealed that the variation in the chemical compositions, namely, replacement of Mn with Co and/or addition of Ti have a very pronounced effect on the structure and mechanical properties of the non-equiatomic Fe-(Co, Mn)-Cr-Ni-Al-(Ti) HEAs which are based on the earlier introduced $\mathrm{Fe}_{36} \mathrm{Mn}_{21} \mathrm{Cr}_{18} \mathrm{Ni}_{15} \mathrm{Al}_{10}$ alloy [29,34]. In terms of the phase composition, the most significant changes were associated with (i) variations in the fraction of the fcc phase; (ii) the presence of the $\mathrm{B} 2 / \mathrm{L} 2_{1}$ precipitates in the bcc phase.

The fraction of the fcc phase in the program alloys varied in a wide range, for example, no fcc phase was found in the $\mathrm{Fe}_{35} \mathrm{Mn}_{20} \mathrm{Cr}_{17} \mathrm{Ni}_{12} \mathrm{Al}_{12} \mathrm{Ti}_{4}$ alloy (Fig. 4) while the $\mathrm{Fe}_{36} \mathrm{Co}_{21} \mathrm{Cr}_{18} \mathrm{Ni}_{15} \mathrm{Al}_{10}$ alloy (Fig. 3) was mostly composed of the fcc phase. Note that although the $\mathrm{L} 2_{1}$ phase has an fcc structure, it can be considered as being built of the bcc and B2 lattices [37]; therefore only the disordered fcc phase is considered in the present analysis. The fcc-bcc transformation in $3 \mathrm{~d}$ transition metals HEAs of different chemical compositions is widely documented [1,38-41]. It was found that the average valence electron concentration parameter $\left(V E C=\Sigma c_{i} V E C_{i}\right.$, where $c_{i}$ and $V E C_{i}$ are the atomic concentration and the valence electron concentration of the $i$ element, respectively) can be effectively used to predict the bcc/fcc phases formation in HEAs. The fcc phase(s) form in HEAs with $V E C>8$, the bcc phase(s) form at $V E C<6.87$ and both the fcc and bcc phases coexist in the alloys with the VEC values between 6.87 and 8.0 [38]. We have plotted the fcc phase fraction in the program alloys against the calculated VEC values (Fig. 8).

Fig. 8 shows a complex, non-monotonic relationship between the fcc fraction and the $V E C$ value. Since only 4 alloys (data points) were examined in the present study, the dependence of the fcc fraction on VEC could not be established reliably. However, the available information suggests that a solely bcc structure can be expected in the alloys with $V E C$ below $\sim 7.2$, and a solely fcc structure will be found in the alloys with $V E C$ above $\sim 7.7$ (the proposed dependence is shown with a dashed line in Fig. 8). In the alloys with VEC of $\sim 7.2-7.7$ a mixture of the fcc and bcc phases is expected, and the fraction of the fcc phase increases in proportion with the $V E C$ value. The expected $V E C$ range for the fcc-bcc mixture is narrower than it was reported previously by Guo et al. (VEC $=6.87-8.0$ [38]), but our VEC value for the transition between the solely bcc and the bcc + fcc structures is rather consistent with the recent data obtained for alloys with mostly bcc/B2 structures $(V E C=7.35[32])$.

The Thermo-Calc software with the TCHEA2 database also predicts the bcc/fcc transformation rather reliably; for example, one can

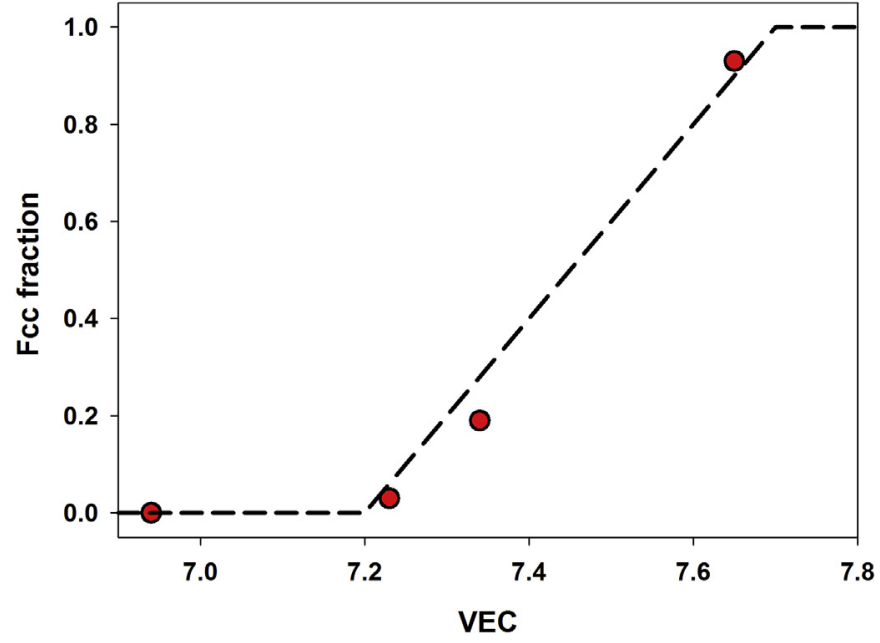

Fig. 8. Dependence of the fcc phase fraction on the valence electron concentration ( $V E C$ ) value for the program alloys. Note that the dashed line is only a guide to eyes.

compare the structures and calculated phase diagrams of the $\mathrm{Fe}_{36} \mathrm{Mn}_{21} \mathrm{Cr}_{18} \mathrm{Ni}_{15} \mathrm{Al}_{10}$ alloy (3\% of the fcc phase, Figs. 2 and $7 \mathrm{a}$ ) and the $\mathrm{Fe}_{36} \mathrm{Co}_{21} \mathrm{Cr}_{18} \mathrm{Ni}_{15} \mathrm{Al}_{10}$ alloy (93\% of the fcc phase, Figs. 3 and $7 \mathrm{~b}$ ). The chemical composition of the constitutive phases (Tables 2 and 3) also correlate with the Thermo-Calc predictions reasonably. An insignificant fraction of the fcc phase along grain boundaries of the $\mathrm{Fe}_{36} \mathrm{Mn}_{21} \mathrm{Cr}_{18} \mathrm{Ni}_{15} \mathrm{Al}_{10}$ alloy (Fig. $2 \mathrm{~b}$ and c) was most likely produced via a solid-state reaction during cooling of the as-solidified bcc phase (Fig. 7a), as well as the B2 precipitates (Fig. 2d). The fcc phase can be removed by proper heat treatment [29].

In turn, the bcc/B2 mixture (Fig. 3e) in the $\mathrm{Fe}_{36} \mathrm{Co}_{21} \mathrm{Cr}_{18} \mathrm{Ni}_{15} \mathrm{Al}_{10}$ alloy was likely produced by a solid-state decomposition of the hightemperature bcc phase that formed at the initial stages of solidification and was mostly replaced by the fcc phase during cooling (Fig. 7b). The microstructure morphology of the $\mathrm{Fe}_{36} \mathrm{Co}_{21} \mathrm{Cr}_{18} \mathrm{Ni}_{15} \mathrm{Al}_{10}$ alloy (coarse fcc grains separated by thick layers of the bcc/B2 mixture; fine bcc/B2 plates (Fig. 3)) supports the suggested sequence of phase transformations. However, note that the experimental fractions of the bcc (0.03) and the B2 (0.04) phases is much lower than those predicted by the phase diagram; this discrepancy can be attributed to a non-equilibrium as-cast condition and/or well-known imperfections of the available databases.

In the alloys with $\mathrm{Ti}$, namely $\mathrm{Fe}_{35} \mathrm{Mn}_{20} \mathrm{Cr}_{17} \mathrm{Ni}_{12} \mathrm{Al}_{12} \mathrm{Ti}_{4}$ and $\mathrm{Fe}_{35} \mathrm{Co}_{20} \mathrm{Cr}_{17} \mathrm{Ni}_{12} \mathrm{Al}_{12} \mathrm{Ti}_{4}$ the $\mathrm{L} 2_{1}$ precipitates were found in the bcc phase instead of the $\mathrm{B} 2$ precipitates in the $\mathrm{Fe}_{35}(\mathrm{Co}$, $\mathrm{Mn})_{20} \mathrm{Cr}_{17} \mathrm{Ni}_{12} \mathrm{Al}_{12} \mathrm{Ti}_{4}$ alloys. The $\mathrm{L} 2_{1}$ phase formation is well documented in the Fe-Cr-Ni-Al-Ti ferritic alloys [35-37,42-44] and in Al-Ticontaining HEAs [45-48] and therefore is not surprising in the $\mathrm{Fe}_{35}$ (Co, $\mathrm{Mn})_{20} \mathrm{Cr}_{17} \mathrm{Ni}_{12} \mathrm{Al}_{12} \mathrm{Ti}_{4}$ alloys. However, note that although the observed $\mathrm{L} 21$ phase is enriched with $\mathrm{Al}$ and Ti (Tables 4 and 5), its composition is 
very far from the ternary $\mathrm{Ni}_{2} \mathrm{AlTi}$ compound (the same is valid for the B2 phase in the $\mathrm{Fe}_{36}(\mathrm{Co}, \mathrm{Mn})_{21} \mathrm{Cr}_{18} \mathrm{Ni}_{15} \mathrm{Al}_{10}$ alloys). A complex chemical composition of the $\mathrm{L} 2{ }_{1}$ phase is most probably due to the complex site occupancy. Analysis of the available ternary phase diagrams [49] shows that 5 (Al-Co-Cr; Al-Co-Ti; Al-Cr-Fe; Al-Fe-Ni; Al-Ni-Ti) and 4 (Al$\mathrm{Cr}-\mathrm{Fe}$; Al-Fe-Ni; Al-Fe-Ti; Al-Ni-Ti) subsystems of the Al-Co-Cr-Fe-Ni-Ti and $\mathrm{Al}-\mathrm{Cr}-\mathrm{Fe}-\mathrm{Mn}-\mathrm{Ni}-\mathrm{Ti}$ systems, respectively, contained the $\mathrm{L} 2_{1}$ compounds. Therefore it seems reasonable that the constitutive elements can easily share the same sites in the $\mathrm{L} 2{ }_{1}$ phase of the multicomponent alloys.

Unlike the B2 phase in the $\mathrm{Fe}_{36}(\mathrm{Co}, \mathrm{Mn})_{21} \mathrm{Cr}_{18} \mathrm{Ni}_{15} \mathrm{Al}_{10}$ alloys, the $\mathrm{L} 21_{1}$ phase formation in the $\mathrm{Fe}_{35}(\mathrm{Co}, \mathrm{Mn})_{20} \mathrm{Cr}_{17} \mathrm{Ni}_{12} \mathrm{Al}_{12} \mathrm{Ti}_{4}$ alloys is not predicted by the Thermo-Calc software with the TCHEA2 database. In both Ti-containing alloys, the $\mathrm{B} 2$ phase is expected to precipitate (Fig. 7c and d). An incorrect prediction of a type of precipitated phases can be ascribed to an imperfect description of the phases with such a complex chemical composition and site occupancy in the available commercial databases [50]. Meanwhile, the tendency of the fcc phase formation in the $\mathrm{Fe}_{35} \mathrm{Co}_{20} \mathrm{Cr}_{17} \mathrm{Ni}_{12} \mathrm{Al}_{12} \mathrm{Ti}_{4}$ alloy was correctly predicted by the equilibrium phase diagram (Fig. 7d). Also, in both Ti-containing alloys the $\mathrm{L} 2{ }_{1}$ phase particles were most likely produced via a solidstate reaction during cooling of the high-temperature bcc phase, similar to the $\mathrm{B} 2$ phase in the $\mathrm{Fe}_{36}(\mathrm{Co}, \mathrm{Mn})_{21} \mathrm{Cr}_{18} \mathrm{Ni}_{15} \mathrm{Al}_{10}$ alloys. The fcc phase in the $\mathrm{Fe}_{35} \mathrm{Co}_{20} \mathrm{Cr}_{17} \mathrm{Ni}_{12} \mathrm{Al}_{12} \mathrm{Ti}_{4}$ alloy, found on the bcc grain boundaries or in form of the lens-shape particles (Fig. 5), can be produced during the solidification in agreement with the calculated phase diagram (Fig. 7d).

The B2 and $\mathrm{L} 21_{1}$ particles in the $\mathrm{Fe}_{36} \mathrm{Mn}_{21} \mathrm{Cr}_{18} \mathrm{Ni}_{15} \mathrm{Al}_{10}$ $\mathrm{Fe}_{35} \mathrm{Mn}_{20} \mathrm{Cr}_{17} \mathrm{Ni}_{12} \mathrm{Al}_{12} \mathrm{Ti}_{4}$ or $\mathrm{Fe}_{35}\left(\mathrm{Co}, \mathrm{Mn}_{20} \mathrm{Cr}_{17} \mathrm{Ni}_{12} \mathrm{Al}_{12} \mathrm{Ti}_{4}\right.$ alloys have the cuboidal or plate-like shape, most probably due to their crystallographic similarity with the bcc matrix [37]. The exact shape of the precipitates is dependent on the elastic and interphase energies $[32,51,52]$, which can be evaluated using the characteristic parameter $L$ [32]:

$L=\frac{\varepsilon^{2} C_{44} r}{S}$

Where $\varepsilon$ is the lattice misfit, $C_{44}$ is the elastic constant of the matrix, $r$ is the average particle size, and $s$ is the average specific interfacial energy. The lattice misfit between bcc and B2 and bcc and $\mathrm{L} 22_{1}$ phases can be calculated as (2) and (3), respectively [32,53]:

$\varepsilon=\frac{2\left(a_{B 2}-a_{b c c}\right)}{\left(a_{B 2}+a_{b c c}\right)}$

$\varepsilon=\frac{2\left(a_{L 21}-2 a_{b c c}\right)}{\left(a_{L 21}+2 a_{b c c}\right)}$

It is generally expected that with an increase of $L$ the shape of the particles will change from spherical to cuboidal and then to plate-like. Using the experimental values of lattice parameters (Table 1) and size of precipitates, and accepting the values of $C_{44}=130 \mathrm{GPa}$ and $s=0.125 \mathrm{~J} / \mathrm{m}^{2}$ [32], the $L$ margin for the $\mathrm{Fe}_{36} \mathrm{Mn}_{21} \mathrm{Cr}_{18} \mathrm{Ni}_{15} \mathrm{Al}_{10}$, $\mathrm{Fe}_{35} \mathrm{Mn}_{20} \mathrm{Cr}_{17} \mathrm{Ni}_{12} \mathrm{Al}_{12} \mathrm{Ti}_{4}$, and $\mathrm{Fe}_{35} \mathrm{Co}_{20} \mathrm{Cr}_{17} \mathrm{Ni}_{12} \mathrm{Al}_{12} \mathrm{Ti}_{4}$ alloys were determined to be $1.08,2.11$, and 3.27 , respectively. The gradual increase of the $L$ value is consistent with the observed changes in the precipitate shape from cuboidal in the $\mathrm{Fe}_{36} \mathrm{Mn}_{21} \mathrm{Cr}_{18} \mathrm{Ni}_{15} \mathrm{Al}_{10}$ alloy and plate-like in the $\mathrm{Fe}_{35} \mathrm{Co}_{20} \mathrm{Cr}_{17} \mathrm{Ni}_{12} \mathrm{Al}_{12} \mathrm{Ti}_{4}$ alloy to a mixture of cuboidal and platelike particles in the $\mathrm{Fe}_{35} \mathrm{Mn}_{20} \mathrm{Cr}_{17} \mathrm{Ni}_{12} \mathrm{Al}_{12} \mathrm{Ti}_{4}$ alloy.

Mechanical properties of the alloys also varied significantly depending on their chemical composition and structure (Fig. 6 and Table 6). The fcc-structured $\mathrm{Fe}_{36} \mathrm{Co}_{21} \mathrm{Cr}_{18} \mathrm{Ni}_{15} \mathrm{Al}_{10}$ was considerably softer than the other alloys. It is generally believed that the fcc HEAs are softer and more ductile than the bcc ones [1]; however in the present case the low strength of the alloy can be mostly attributed to the absence of any strengthening precipitates in the fcc matrix of the $\mathrm{Fe}_{36} \mathrm{Co}_{21} \mathrm{Cr}_{18} \mathrm{Ni}_{15} \mathrm{Al}_{10}$ alloy (Fig. 3). The lower strength of the
$\mathrm{Fe}_{36} \mathrm{Co}_{21} \mathrm{Cr}_{18} \mathrm{Ni}_{15} \mathrm{Al}_{10}$ alloy also shows that a simple addition of elements with high melting temperatures (i.e. replacement of $\mathrm{Mn}$ with $\mathrm{Co}$ ) is not sufficient for improvement of the high-temperature properties; particular attention has to be paid to the changes in phase composition. In turn, all the bcc-based alloys $\left(\mathrm{Fe}_{36} \mathrm{Mn}_{21} \mathrm{Cr}_{18} \mathrm{Ni}_{15} \mathrm{Al}_{10}\right.$ and $\mathrm{Fe}_{35}(\mathrm{Mn}$, Co) ${ }_{20} \mathrm{Cr}_{17} \mathrm{Ni}_{12} \mathrm{Al}_{12} \mathrm{Ti}_{4}$ ) had high compression strength which can be associated with the presence of the fine B2/L2 1 particles (Figs. 2, 4 and 5).

However, due to significant differences in the structure of the alloys, it is impossible to establish exactly which factor(s) controls the mechanical behavior of the precipitation-strengthened alloys. Despite qualitatively similar microstructure (mostly cuboidal precipitates into bcc matrix (Figs. 2 and 4)), the $\mathrm{Fe}_{35} \mathrm{Mn}_{20} \mathrm{Cr}_{17} \mathrm{Ni}_{12} \mathrm{Al}_{12} \mathrm{Ti}_{4}$ alloy was considerably stronger than the $\mathrm{Fe}_{36} \mathrm{Mn}_{21} \mathrm{Cr}_{18} \mathrm{Ni}_{15} \mathrm{Al}_{10}$ alloy at room temperature and $400{ }^{\circ} \mathrm{C}$ (Table 6). Given the quantitative difference between two alloys in the bcc grain sizes $(200 \mu \mathrm{m}$ in the $\mathrm{Fe}_{36} \mathrm{Mn}_{21} \mathrm{Cr}_{18} \mathrm{Ni}_{15} \mathrm{Al}_{10}$ alloy vs. $30 \mu \mathrm{m}$ in the $\mathrm{Fe}_{35} \mathrm{Mn}_{20} \mathrm{Cr}_{17} \mathrm{Ni}_{12} \mathrm{Al}_{12} \mathrm{Ti}_{4}$ alloy), the type of precipitates (B2 vs. L2 1 ), their sizes $(240 \mathrm{~nm}$ vs $190 \mathrm{~nm}$ ) and fractions ( 0.38 and 0.42), it is hard to deduce what are the exact reasons of higher strength of the Ti-containing alloy. Meanwhile the mostly lamellar structure should be the mean reason for the impressive strength of the $\mathrm{Fe}_{35} \mathrm{Co}_{20} \mathrm{Cr}_{17} \mathrm{Ni}_{12} \mathrm{Al}_{12} \mathrm{Ti}_{4}$ alloy (Fig. 5) at both room and elevated $\left(\leq 600^{\circ} \mathrm{C}\right)$ temperatures; in this case long lamellae of the $\mathrm{L} 21$ phase effectively restricts the movement of dislocations in the "channels" of the bcc phase. However, the presence of the fcc particles which are free from precipitates (see Fig. 5b) can have a negative effect on the strength of the alloy.

The ductility of the alloys is also affected by their chemical composition and structure (Table 6). Similar compression ductility of the $\mathrm{Fe}_{36} \mathrm{Mn}_{21} \mathrm{Cr}_{18} \mathrm{Ni}_{15} \mathrm{Al}_{10}$ and $\mathrm{Fe}_{36} \mathrm{Co}_{21} \mathrm{Cr}_{18} \mathrm{Ni}_{15} \mathrm{Al}_{10}$ alloys at all testing temperatures may seem surprising as their microstructures and strength characteristics are significantly different (Figs. 2 and 3). However, one must keep in mind that compression is a "soft" testing scheme, while tensile ductility of the two alloys can be distinctively different.

The Ti-containing alloys have lower ductility at room temperature; in addition the $\mathrm{Fe}_{35} \mathrm{Co}_{20} \mathrm{Cr}_{17} \mathrm{Ni}_{12} \mathrm{Al}_{12} \mathrm{Ti}_{4}$ alloy is less ductile than the other alloys at $400{ }^{\circ} \mathrm{C}$. Perhaps, the lower ductility of the Ti-containing alloys can be associated with the bcc and $\mathrm{L} 21_{1}$ lamellar mixture formation. Although in the $\mathrm{Fe}_{35} \mathrm{Mn}_{20} \mathrm{Cr}_{17} \mathrm{Ni}_{12} \mathrm{Al}_{12} \mathrm{Ti}_{4}$ alloy such structures occupy minor areas (Fig. 4b), due to lower ductility (in comparison with the major bcc + cuboidal $\mathrm{L}_{1}$ structure) they can serve as preferred sites for crack initiation, thereby limiting the ductility of the alloy.

In the $\mathrm{Fe}_{35} \mathrm{Co}_{20} \mathrm{Cr}_{17} \mathrm{Ni}_{12} \mathrm{Al}_{12} \mathrm{Ti}_{4}$ alloy bcc $+\mathrm{L} 2_{1}$ lamellae are the major structural constituent, nevertheless the alloy has reasonable ductility and strain hardening capacity (Fig. 6d, Table 6), at least in compression. The ductility of the alloy can be attributed to the presence of a relatively high amount (0.17) of the precipitate-free fcc phase. Single fcc phase alloys are known for their exceptional ductility and good strain hardening [2,54-56]. Therefore, the fcc phase presence, especially at the grain boundaries, can provide effective strain accommodation for the alloy mostly composed of the hard bcc + L2 $2_{1}$ lamellar mixture and can promote the ductility of the alloy.

In general, the bcc-based precipitation strengthened alloys examined in this study, namely the $\mathrm{Fe}_{36} \mathrm{Mn}_{21} \mathrm{Cr}_{18} \mathrm{Ni}_{15} \mathrm{Al}_{10}$, $\mathrm{Fe}_{35} \mathrm{Mn}_{20} \mathrm{Cr}_{17} \mathrm{Ni}_{12} \mathrm{Al}_{12} \mathrm{Ti}_{4}$, and $\mathrm{Fe}_{35} \mathrm{Co}_{20} \mathrm{Cr}_{17} \mathrm{Ni}_{12} \mathrm{Al}_{12} \mathrm{Ti}_{4}$ alloys, exhibit attractive strength at temperatures up to $400-600{ }^{\circ} \mathrm{C}$ (Table 6). Fig. 9 shows a comparison between the specific yield strengths of the reported alloys; several other HEAs based on transition elements (an $\mathrm{Al}_{10} \mathrm{Co}_{25} \mathrm{Cr}_{8} \mathrm{Fe}_{15} \mathrm{Ni}_{36} \mathrm{Ti}_{6}$ alloy with an fcc/ $/ 1_{2}$ structure [23], $\mathrm{Al}_{0.7} \mathrm{CoCrFe}_{2} \mathrm{Ni}$ and $\mathrm{Fe}_{34} \mathrm{Cr}_{34} \mathrm{Ni}_{14} \mathrm{Al}_{14} \mathrm{Co}_{4}$ alloys with a bcc/B2 structure mostly [31,33]), a commercial nickel-based superalloy Inconel 718 [57] and a duplex stainless steel S32205 [58].

Fig. 9 clearly shows that the $\mathrm{Fe}_{35} \mathrm{Co}_{20} \mathrm{Cr}_{17} \mathrm{Ni}_{12} \mathrm{Al}_{12} \mathrm{Ti}_{4}$ alloy is stronger than any other transition metal HEAs at temperatures below $800^{\circ} \mathrm{C}$. The same alloy is considerably stronger than even the Ni-based 


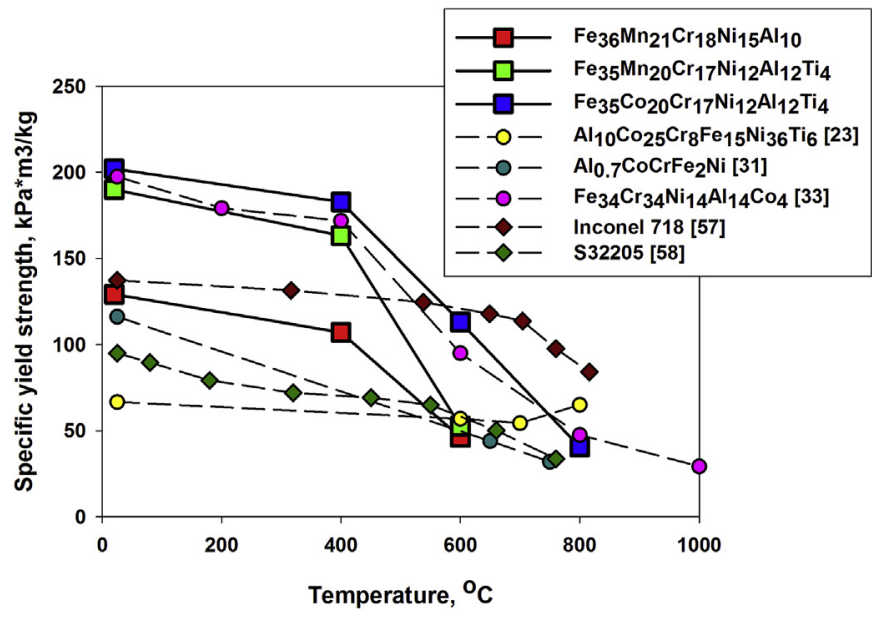

Fig. 9. Temperature dependence of the specific yield strength of the program $\mathrm{Fe}_{36} \mathrm{Mn}_{21} \mathrm{Cr}_{18} \mathrm{Ni}_{15} \mathrm{Al}_{10}, \mathrm{Fe}_{35} \mathrm{Mn}_{20} \mathrm{Cr}_{17} \mathrm{Ni}_{12} \mathrm{Al}_{12} \mathrm{Ti}_{4}$, and $\mathrm{Fe}_{35} \mathrm{Co}_{20} \mathrm{Cr}_{17} \mathrm{Ni}_{12} \mathrm{Al}_{12} \mathrm{Ti}_{4}$ alloys and several other transition metal HEAs and commercial alloys.

Inconel 718 alloy at temperatures from room to $400{ }^{\circ} \mathrm{C}$ and has very similar strength at $600{ }^{\circ} \mathrm{C}$. The $\mathrm{Fe}_{35} \mathrm{Mn}_{20} \mathrm{Cr}_{17} \mathrm{Ni}_{12} \mathrm{Al}_{12} \mathrm{Ti}_{4}$ alloy has specific strength close to that of the $\mathrm{Fe}_{35} \mathrm{Co}_{20} \mathrm{Cr}_{17} \mathrm{Ni}_{12} \mathrm{Al}_{12} \mathrm{Ti}_{4}$ at $25^{\circ} \mathrm{C}$ and $400{ }^{\circ} \mathrm{C}$, but it is much weaker at $600^{\circ} \mathrm{C}$; meanwhile the $\mathrm{Fe}_{36} \mathrm{Mn}_{21} \mathrm{Cr}_{18} \mathrm{Ni}_{15} \mathrm{Al}_{10}$ alloy has lower strength in the whole studied temperature interval. Overall, it can be concluded that the examined alloys, especially the Ti-containing ones, have the very competitive specific strength and can be considered for potential structural application for temperatures up to $600^{\circ} \mathrm{C}$.

In summary, the presented study has revealed that the non-equiatomic Fe-(Co, Mn)-Cr-Ni-Al-(Ti) HEAs with mostly the bcc/B2 or bcc/ $\mathrm{L} 2{ }_{1}$ structures can have promising mechanical properties for hightemperature applications. In addition, microstructure parameters, including, but not limited to, the fraction of the fcc, B2, and L2 1 phases and the morphology of the $\mathrm{L} 21$ precipitates, can be controlled by varying the chemical compositions of the alloys. The calculated phase diagrams also suggested wide possibilities for the microstructure control via heat/thermomechanical treatment in most of the alloys. As a result, alloys with desired microstructures for even better mechanical properties can potentially be developed based on the Fe-(Co, Mn)-Cr-NiAl-(Ti) system. However, additional studies are still needed to establish more complete understanding of the composition-structure-properties relationships in such alloys.

\section{Conclusions}

In the present work four non-equiatomic $\mathrm{Fe}-(\mathrm{Co}, \mathrm{Mn})-\mathrm{Cr}-\mathrm{Ni}-\mathrm{Al}-(\mathrm{Ti})$ high entropy alloys, namely $\mathrm{Fe}_{36} \mathrm{Mn}_{21} \mathrm{Cr}_{18} \mathrm{Ni}_{15} \mathrm{Al}_{10}, \mathrm{Fe}_{36} \mathrm{Co}_{21} \mathrm{Cr}_{18} \mathrm{Ni}_{15} \mathrm{Al}_{10}$, $\mathrm{Fe}_{35} \mathrm{Mn}_{20} \mathrm{Cr}_{17} \mathrm{Ni}_{12} \mathrm{Al}_{12} \mathrm{Ti}_{4}$, and $\mathrm{Fe}_{35} \mathrm{Co}_{20} \mathrm{Cr}_{17} \mathrm{Ni}_{12} \mathrm{Al}_{12} \mathrm{Ti}_{4}$ alloys, after arc melting and casting were examined. Both structure and mechanical properties showed pronounced dependence on the chemical composition of the alloys:

1) The Ti-free Fe-(Co, Mn)-Cr-Ni-Al alloys were composed of the bcc, fcc, and $\mathrm{B} 2$ phases. The $\mathrm{Fe}_{36} \mathrm{Co}_{21} \mathrm{Cr}_{18} \mathrm{Ni}_{15} \mathrm{Al}_{10}$ alloy had the precipitate-free fcc matrix with a small amount of the mixed bcc and B2 phases at the fcc grain boundaries. In turn, the $\mathrm{Fe}_{36} \mathrm{Mn}_{21} \mathrm{Cr}_{18} \mathrm{Ni}_{15} \mathrm{Al}_{10}$ alloy was composed of the bcc matrix with the embedded cuboidal B2 precipitates. A small amount of the fcc phase at the bcc grain boundaries was also detected.

2) The Fe-(Co, Mn)-Cr-Ni-Al-Ti alloys were mostly composed of the bcc matrix phase and $\mathrm{L} 2{ }_{1}$ precipitates. In the $\mathrm{Fe}_{35} \mathrm{Mn}_{20} \mathrm{Cr}_{17} \mathrm{Ni}_{12} \mathrm{Al}_{12} \mathrm{Ti}_{4}$ the $\mathrm{L} 2{ }_{1}$ particles mostly had the cuboidal shape, while in the $\mathrm{Fe}_{35} \mathrm{Co}_{20} \mathrm{Cr}_{17} \mathrm{Ni}_{12} \mathrm{Al}_{12} \mathrm{Ti}_{4}$ alloy the plate-like precipitates were observed. In addition, a substantial amount of the fcc phase (0.17) was found in the Co-containing alloy.

3) The amount of the fcc phase in the experimental alloys was found to be dependent on the average valence electron concentration (VEC) value. The equilibrium phase diagrams constructed by the ThermoCalc software also predicted the formation of the bcc and fcc phases (and B2 in Ti-free alloys) reliably. However, the transition between the $\mathrm{B} 2$ precipitates in the Ti-free alloys and the $\mathrm{L} 21_{1}$ precipitates in the alloys with $\mathrm{Ti}$ was not predicted by Thermo-Calc.

4) The fcc-structured $\mathrm{Fe}_{36} \mathrm{Co}_{21} \mathrm{Cr}_{18} \mathrm{Ni}_{15} \mathrm{Al}_{10}$ alloy had the lowest strength among the examined alloys both at room and elevated temperatures. The alloys with the bcc + cuboidal B2/L2 1 structure, namely $\mathrm{Fe}_{36} \mathrm{Mn}_{21} \mathrm{Cr}_{18} \mathrm{Ni}_{15} \mathrm{Al}_{10}$ and $\mathrm{Fe}_{35} \mathrm{Mn}_{20} \mathrm{Cr}_{17} \mathrm{Ni}_{12} \mathrm{Al}_{12} \mathrm{Ti}_{4}$, had much higher strength at room temperature and $400{ }^{\circ} \mathrm{C}$, but softened pronouncedly at $600{ }^{\circ} \mathrm{C}$. The $\mathrm{Fe}_{35} \mathrm{Co}_{20} \mathrm{Cr}_{17} \mathrm{Ni}_{12} \mathrm{Al}_{12} \mathrm{Ti}_{4}$ alloy with the bcc matrix and plate-like $\mathrm{L} 2{ }_{1}$ precipitates had the highest strength among the examined alloys at room temperature and retained high strength even at $600{ }^{\circ} \mathrm{C}$. The comparison of the specific strength of the precipitation-strengthened $\mathrm{Fe}-(\mathrm{Co}, \mathrm{Mn})-\mathrm{Cr}-\mathrm{Ni}$-Al-(Ti) alloys with other $3 \mathrm{~d}$ transition metals and commercial alloys showed the potential of the examined alloys as high-temperature materials.

\section{Acknowledgments}

The authors gratefully acknowledge the financial support from the Russian Science Foundation Grant No. 18-19-00003. The authors are grateful to the personnel of the Joint Research Center, «Technology and Materials», Belgorod State University, for their assistance with the instrumental analysis.

\section{References}

[1] Y. Zhang, T.T. Zuo, Z. Tang, M.C. Gao, K.A. Dahmen, P.K. Liaw, Z.P. Lu, Microstructures and properties of high-entropy alloys, Prog. Mater. Sci. 61 (2014), https://doi.org/10.1016/j.pmatsci.2013.10.001.

[2] D.B. Miracle, O.N. Senkov, A critical review of high entropy alloys and related concepts, Acta Mater. 122 (2017) 448-511, https://doi.org/10.1016/j.actamat. 2016.08.081.

[3] M.-H. Tsai, J.-W. Yeh, High-entropy alloys: a critical review, Mater. Res. Lett. 2 (2014) 107-123, https://doi.org/10.1080/21663831.2014.912690.

[4] E.J. Pickering, N.G. Jones, High-entropy alloys: a critical assessment of their founding principles and future prospects, Int. Mater. Rev. (2016) 183-202, https:// doi.org/10.1080/09506608.2016.1180020.

[5] J.-W. Yeh, S.-K. Chen, S.-J. Lin, J.-Y. Gan, T.-S. Chin, T.-T. Shun, C.-H. Tsau, S.Y. Chang, Nanostructured high-entropy alloys with multiple principal elements: novel alloy design concepts and outcomes, Adv. Eng. Mater. 6 (2004) 299-303, https://doi.org/10.1002/adem.200300567.

[6] S. Gorsse, D.B. Miracle, O.N. Senkov, Mapping the world of complex concentrated alloys, Acta Mater. 135 (2017) 177-187, https://doi.org/10.1016/j.actamat.2017. 06.027.

[7] S. Praveen, H.S. Kim, High-entropy alloys: potential candidates for high-temperature applications - an overview, Adv. Eng. Mater. 20 (2018) 1700645, , https://doi. org/10.1002/adem.201700645.

[8] J. Chen, X. Zhou, W. Wang, B. Liu, Y. Lv, W. Yang, D. Xu, Y. Liu, A review on fundamental of high entropy alloys with promising high-temperature properties, J. Alloy. Comp. 760 (2018) 15-30, https://doi.org/10.1016/j.jallcom.2018.05.067.

[9] O.N. Senkov, G.B. Wilks, J.M. Scott, D.B. Miracle, Mechanical properties of Nb 25Mo 25Ta 25W 25 and V 20Nb 20Mo 20Ta 20W 20 refractory high entropy alloys, Intermetallics 19 (2011) 698-706, https://doi.org/10.1016/j.intermet.2011.01. 004.

[10] O.N. Senkov, S.V. Senkova, C. Woodward, D.B. Miracle, Low-density, refractory multi-principal element alloys of the $\mathrm{Cr}-\mathrm{Nb}-\mathrm{Ti}-\mathrm{V}-\mathrm{Zr}$ system: microstructure and phase analysis, Acta Mater. 61 (2013) 1545-1557, https://doi.org/10.1016/j. actamat.2012.11.032.

[11] O.N. Senkov, J.K. Jensen, A.L. Pilchak, D.B. Miracle, H.L. Fraser, Compositional variation effects on the microstructure and properties of a refractory high-entropy superalloy AlMo0.5NbTa0.5TiZr, Mater. Des. 139 (2018) 498-511, https://doi.org/ 10.1016/j.matdes.2017.11.033.

[12] O.N. Senkov, S. Rao, K.J. Chaput, C. Woodward, Compositional effect on microstructure and properties of NbTiZr-based complex concentrated alloys, Acta Mater. 151 (2018) 201-215, https://doi.org/10.1016/j.actamat.2018.03.065.

[13] N.Y. Yurchenko, N.D. Stepanov, S.V. Zherebtsov, M.A. Tikhonovsky, G.A. Salishchev, Structure and mechanical properties of B2 ordered refractory AlNbTiVZrx (x = 0-1.5) high-entropy alloys, Mater. Sci. Eng. 704 (2017) 82-90, https://doi.org/10.1016/j.msea.2017.08.019.

[14] N.D. Stepanov, N.Y. Yurchenko, D.V. Skibin, M.A. Tikhonovsky, G.A. Salishchev, 
Structure and mechanical properties of the $\mathrm{AlCr}_{\mathrm{x}} \mathrm{NbTiV}(\mathrm{x}=0,0.5,1,1.5)$ high entropy alloys, J. Alloy. Comp. 652 (2015) 266-280, https://doi.org/10.1016/j. jallcom.2015.08.224.

[15] N.Y. Yurchenko, N.D. Stepanov, D.G. Shaysultanov, M.A. Tikhonovsky, G.A. Salishchev, Effect of $\mathrm{Al}$ content on structure and mechanical properties of the $\mathrm{Al}_{\mathrm{x}} \mathrm{CrNbTiVZr}(\mathrm{x}=0 ; 0.25 ; 0.5 ; 1)$ high-entropy alloys, Mater. Char. (2016), https://doi.org/10.1016/j.matchar.2016.09.039.

[16] H. Chen, A. Kauffmann, B. Gorr, D. Schliephake, C. Seemüller, J.N.N. Wagner, H.J.J. Christ, M. Heilmaier, Microstructure and mechanical properties at elevated temperatures of a new Al-containing refractory high-entropy alloy Nb-Mo-Cr-Ti-Al, J. Alloy. Comp. 661 (2016) 206-215, https://doi.org/10.1016/j.jallcom.2015.11. 050.

[17] W. Chen, Q.H. Tang, H. Wang, Y.C. Xie, X.H. Yan, P.Q. Dai, Microstructure and mechanical properties of a novel refractory AlNbTiZr high-entropy alloy, Mater. Sci. Technol. (2018) 1-7, https://doi.org/10.1080/02670836.2018.1446267.

[18] Z.D. Han, N. Chen, S.F. Zhao, L.W. Fan, G.N. Yang, Y. Shao, K.F. Yao, Effect of Ti additions on mechanical properties of NbMoTaW and VNbMoTaW refractory high entropy alloys, Intermetallics 84 (2017) 153-157, https://doi.org/10.1016/j. intermet.2017.01.007.

[19] D.B. Miracle, J.D. Miller, O.N. Senkov, C. Woodward, M.D. Uchic, J. Tiley, Exploration and development of high entropy alloys for structural applications, Entropy 16 (2014) 494-525, https://doi.org/10.3390/e16010494.

[20] O.N. Senkov, J.D. Miller, D.B. Miracle, C. Woodward, Accelerated exploration of multi-principal element alloys with solid solution phases, Nat. Commun. 6 (2015) 6529, https://doi.org/10.1038/ncomms7529.

[21] T.M. Pollock, S. Tin, Nickel-based superalloys for advanced turbine engines: chemistry, microstructure and properties, J. Propul. Power 22 (2006) 361-374, https://doi.org/10.2514/1.18239.

[22] A.M. Manzoni, S. Singh, H.M. Daoud, R. Popp, R. Völkl, U. Glatzel, N. Wanderka, On the path to optimizing the Al-Co-Cr-Cu-Fe-Ni-Ti high entropy alloy family for high temperature applications, Entropy 18 (2016), https://doi.org/10.3390/ e18040104.

[23] H.M. Daoud, A.M. Manzoni, N. Wanderka, U. Glatzel, High-temperature tensile strength of Al10Co25Cr8Fe15Ni36Ti6 compositionally complex alloy (HighEntropy alloy), JOM 67 (2015) 2271-2277, https://doi.org/10.1007/s11837-015 1484-7.

[24] T.-K. Tsao, A.-C. Yeh, C.-M. Kuo, H. Murakami, On the superior high temperature hardness of precipitation strengthened high entropy Ni-based alloys, Adv. Eng. Mater. 19 (2017) 1600475, , https://doi.org/10.1002/adem.201600475.

[25] T.-K. Tsao, A.-C. Yeh, C.-M. Kuo, H. Murakami, High temperature oxidation and corrosion properties of high entropy superalloys, Entropy 18 (2016) 62, https://doi. org/10.3390/e18020062

[26] T.-K. Tsao, A.-C. Yeh, H. Murakami, The microstructure stability of precipitation strengthened medium to high entropy superalloys, Metall. Mater. Trans. 48 (2017) 2435-2442, https://doi.org/10.1007/s11661-017-4037-6.

[27] T.-K. Tsao, A.-C. Yeh, C.-M. Kuo, K. Kakehi, H. Murakami, J.-W. Yeh, S.-R. Jian, The high temperature tensile and creep behaviors of high entropy superalloy, Sci. Rep. 7 (2017) 12658, https://doi.org/10.1038/s41598-017-13026-7.

[28] A. Manzoni, S. Haas, H. Daoud, U. Glatzel, C. Förster, N. Wanderka, A.M. Manzoni, S. Haas, H. Daoud, U. Glatzel, C. Förster, N. Wanderka, Tensile behavior and evolution of the phases in the Al10Co25Cr8Fe15Ni36Ti6 compositionally complex/ high entropy alloy, Entropy 20 (2018) 646, https://doi.org/10.3390/e20090646.

[29] D.G. Shaysultanov, G.A. Salishchev, Y.V. Ivanisenko, S.V. Zherebtsov, M.A. Tikhonovsky, N.D. Stepanov, Novel Fe36Mn21Cr18Ni15Al10high entropy alloy with bcc/B2 dual-phase structure, J. Alloy. Comp. 705 (2017) 756-763, https://doi.org/10.1016/j.jallcom.2017.02.211.

[30] L. Zhang, D. Zhou, B. Li, Anomalous microstructure and excellent mechanical properties of $\mathrm{Ni} 35 \mathrm{Al} 21.67 \mathrm{Cr} 21.67 \mathrm{Fe} 21.67 \mathrm{high}$-entropy alloy with BCC and B2 structure, Mater. Lett. 216 (2018) 252-255, https://doi.org/10.1016/j.matlet. 2018.01.124.

[31] Q. Wang, Y. Ma, B. Jiang, X. Li, Y. Shi, C. Dong, P.K. Liaw, A cuboidal B2 nanoprecipitation-enhanced body-centered-cubic alloy Al0.7CoCrFe2Ni with prominent tensile properties, Scr. Mater. 120 (2016) 85-89, https://doi.org/10.1016/j. scriptamat.2016.04.014

[32] Y. Ma, Q. Wang, B.B. Jiang, C.L. Li, J.M. Hao, X.N. Li, C. Dong, T.G. Nieh, Controlled formation of coherent cuboidal nanoprecipitates in body-centered cubic high-entropy alloys based on $\mathrm{Al} 2$ (Ni,Co,Fe,Cr) 14 compositions, Acta Mater. 147 (2018) 213-225, https://doi.org/10.1016/j.actamat.2018.01.050.

[33] Y. Zhou, X. Jin, L. Zhang, X. Du, B. Li, A hierarchical nanostructured Fe $34 \mathrm{Cr} 34 \mathrm{Ni}$ $14 \mathrm{Al} 14$ Co 4 high-entropy alloy with good compressive mechanical properties, Mater. Sci. Eng. (2018), https://doi.org/10.1016/j.msea.2018.01.034.

[34] N.D. Stepanov, D.G. Shaysultanov, R.S. Chernichenko, M.A. Tikhonovsky, S.V. Zherebtsov, Effect of $\mathrm{Al}$ on structure and mechanical properties of Fe-Mn-Cr-Ni$\mathrm{Al}$ non-equiatomic high entropy alloys with high Fe content, J. Alloy. Comp. 770 (2018) 194-203, https://doi.org/10.1016/j.jallcom.2018.08.093.

[35] G. Song, Z. Sun, L. Li, X. Xu, M. Rawlings, C.H. Liebscher, B. Clausen, J. Poplawsky, D.N. Leonard, S. Huang, Z. Teng, C.T. Liu, M.D. Asta, Y. Gao, D.C. Dunand, G. Ghosh, M. Chen, M.E. Fine, P.K. Liaw, Ferritic alloys with extreme creep resistance via coherent hierarchical precipitates, Sci. Rep. 5 (2015) 16327, https:// doi.org/10.1038/srep16327.
[36] M.J.S. Rawlings, C.H. Liebscher, M. Asta, D.C. Dunand, Effect of titanium additions upon microstructure and properties of precipitation-strengthened $\mathrm{Fe}-\mathrm{Ni}-\mathrm{Al}-\mathrm{Cr}$ ferritic alloys, Acta Mater. 128 (2017) 103-112, https://doi.org/10.1016/J. ACTAMAT.2017.02.028

[37] C.H. Liebscher, V.R. Radmilović, U. Dahmen, N.Q. Vo, D.C. Dunand, M. Asta, G. Ghosh, A hierarchical microstructure due to chemical ordering in the bcc lattice: early stages of formation in a ferritic Fe-Al-Cr-Ni-Ti alloy, Acta Mater. 92 (2015) 220-232, https://doi.org/10.1016/j.actamat.2015.03.043.

[38] S. Guo, C. Ng, J. Lu, C.T. Liu, Effect of valence electron concentration on stability of fcc or bcc phase in high entropy alloys, J. Appl. Phys. 109 (2011) 103505, https:// doi.org/10.1063/1.3587228.

[39] D. Choudhuri, B. Gwalani, S. Gorsse, C.V. Mikler, R.V. Ramanujan, M.A. Gibson, R. Banerjee, Change in the primary solidification phase from fcc to bcc-based B2 in high entropy or complex concentrated alloys, Scr. Mater. 127 (2017), https://doi. org/10.1016/j.scriptamat.2016.09.023.

[40] J.Y. He, W.H. Liu, H. Wang, Y. Wu, X.J. Liu, T.G. Nieh, Z.P. Lu, Effects of Al addition on structural evolution and tensile properties of the FeCoNiCrMn high-entropy alloy system, Acta Mater. 62 (2014) 105-113, https://doi.org/10.1016/j.actamat.2013. 09.037.

[41] M. Li, J. Gazquez, A. Borisevich, R. Mishra, K.M. Flores, Evaluation of microstructure and mechanical property variations in AlxCoCrFeNi high entropy alloys produced by a high-throughput laser deposition method, Intermetallics 95 (2018) 110-118, https://doi.org/10.1016/j.intermet.2018.01.021.

[42] C.H. Liebscher, V. Radmilovic, U. Dahmen, M. Asta, G. Ghosh, On the formation of hierarchically structured L2 1 -Ni2TiAl type precipitates in a ferritic alloy, J. Mater. Sci. 48 (2013) 2067-2075, https://doi.org/10.1007/s10853-012-6980-3.

[43] S.-I. Baik, M.J.S. Rawlings, D.C. Dunand, Atom probe tomography study of Fe-Ni-AlCr-Ti ferritic steels with hierarchically-structured precipitates, Acta Mater. 144 (2018) 707-715, https://doi.org/10.1016/J.ACTAMAT.2017.11.013.

[44] G. Song, Z. Sun, J.D. Poplawsky, Y. Gao, P.K. Liaw, Microstructural evolution of single Ni2TiAl or hierarchical NiAl/Ni2TiAl precipitates in Fe-Ni-Al-Cr-Ti ferritic alloys during thermal treatment for elevated-temperature applications, Acta Mater. 127 (2017) 1-16, https://doi.org/10.1016/J.ACTAMAT.2017.01.011.

[45] R. Feng, M.C. Gao, C. Lee, M. Mathes, T. Zuo, S. Chen, J.A. Hawk, Y. Zhang, P.K. Liaw, Design of light-weight high-entropy alloys, Entropy 18 (2016) 333, https://doi.org/10.3390/e18090333.

[46] R. Feng, M.C. Gao, C. Zhang, W. Guo, J.D. Poplawsky, F. Zhang, J.A. Hawk, J.C. Neuefeind, Y. Ren, P.K. Liaw, Phase stability and transformation in a lightweight high-entropy alloy, Acta Mater. (2018), https://doi.org/10.1016/j.actamat. 2017.12.061.

[47] D. Choudhuri, T. Alam, T. Borkar, B. Gwalani, A.S. Mantri, S.G. Srinivasan, M.A. Gibson, R. Banerjee, Formation of a Huesler-like L21 phase in a CoCrCuFeNiAlTi high-entropy alloy, Scr. Mater. 100 (2015) 36-39, https://doi.org/ 10.1016/j.scriptamat.2014.12.006.

[48] J.Y. He, H. Wang, H.L. Huang, X.D. Xu, M.W. Chen, Y. Wu, X.J. Liu, T.G. Nieh, K. An, Z.P. Lu, A precipitation-hardened high-entropy alloy with outstanding tensile properties, Acta Mater. 102 (2016) 187-196, https://doi.org/10.1016/j.actamat. 2015.08.076.

[49] SpringerMaterials - properties of materials, (n.d.). https://materials.springer.com/ (Accessed 18 June 2018)

[50] O.N. Senkov, D.B. Miracle, K.J. Chaput, J.-P. Couzinie, Development and exploration of refractory high entropy alloys-a review, J. Mater. Res. (2018) 1-37, https://doi.org/10.1557/jmr.2018.153.

[51] M.E. Thompson, C.S. Su, P.W. Voorhees, The equilibrium shape of a misfitting precipitate, Acta Metall. Mater. 42 (1994) 2107-2122, https://doi.org/10.1016/ 0956-7151(94)90036-1.

[52] P.W. Voorhees, G.B. McFadden, W.C. Johnson, On the morphological development of second-phase particles in elastically-stressed solids, Acta Metall. Mater. 40 (1992) 2979-2992, https://doi.org/10.1016/0956-7151(92)90462-N.

[53] F. Qian, J. Sharp, W.M. Rainforth, Characterisation of L21-ordered Ni2TiAl precipitates in FeMn maraging steels, Mater. Char. 118 (2016) 199-205, https://doi. org/10.1016/J.MATCHAR.2016.05.026.

[54] F. Otto, A. Dlouhý, C. Somsen, H. Bei, G. Eggeler, E.P. George, The influences of temperature and microstructure on the tensile properties of a CoCrFeMnNi highentropy alloy, Acta Mater. 61 (2013) 5743-5755, https://doi.org/10.1016/j. actamat.2013.06.018.

[55] N. Stepanov, M. Tikhonovsky, N. Yurchenko, D. Zyabkin, M. Klimova, S. Zherebtsov, A. Efimov, G. Salishchev, Effect of cryo-deformation on structure and properties of CoCrFeNiMn high-entropy alloy, Intermetallics 59 (2015) 8-17, https://doi.org/10.1016/j.intermet.2014.12.004.

[56] M. Klimova, N. Stepanov, D. Shaysultanov, R. Chernichenko, N. Yurchenko, V. Sanin, S. Zherebtsov, Microstructure and mechanical properties evolution of the $\mathrm{Al}$, C-containing CoCrFeNiMn-type high-entropy alloy during cold rolling, Materials 11 (2017) 53, https://doi.org/10.3390/ma11010053.

[57] INCONEL ${ }^{\oplus}$ alloy 718, (n.d.). http://www.specialmetals.com/assets/smc documents/inconel alloy 718.pdf (Accessed 13 June 2018).

[58] J. Chen, B. Young, Stress-strain curves for stainless steel at elevated temperatures, Eng. Struct. 28 (2006) 229-239, https://doi.org/10.1016/J.ENGSTRUCT.2005.07. 005. 